This is the peer reviewed accepted version (Author's Accepted Manuscript) of the following article: Barbarand, J., Marques, F.O., Hildenbrand, A, Pinna-Jamme, R., Nogueira, C.R.. Quidelleur, X., Noronha, F., 2021. Thermal evolution of onshore West Iberia: A better understanding of the ages of breakup and rift-to-drift in the IberiaNewfoundland Rift. Tectonophysics 813, 228926 (2021), which has been published in final form at https://doi.org/10.1016/j.tecto.2021.228926. This article may be used for non-commercial purposes in accordance with ElsevierTerms and Conditions for Use of Self-Archived Versions. 


\section{Thermal evolution of onshore west Iberia: a better understanding of the ages of breakup and rift-to-drift in the Iberia-Newfoundland Rift}

5 Barbarand, J. ${ }^{\left({ }^{*}\right)}$, Marques, F. O. ${ }^{(2)}$, Hildenbrand, A. ${ }^{(1)}$, Pinna Jamme, R.

(1), Nogueira, C.R. (2)

(1) Université Paris-Saclay, CNRS, GEOPS, Orsay, 91405, France

8

(2) Universidade de Lisboa, Lisboa, Portugal

*Corresponding author: jocelyn.barbarand@universite-paris-saclay.fr 


\section{Abstract}

The age of breakup which formed the Central-North Atlantic has been debated for many decades and is still subject to debate: from ca. $150 \mathrm{Ma}$ to $110 \mathrm{Ma}$. To address this issue, we have carried out a thermochronological study of the eastern margin of the rifted IberiaNewfoundland sector. New apatite fission-track (AFT) data acquired on samples from the footwall (Variscan basement) and one sample (Triassic of the Lusitanian Basin) from the hanging wall of the principal normal fault bounding the basin. Thermal history of western Iberia can be then reconstructed since ca. 250 Ma. Fission-track ages of Variscan granitoids (whose crystallization age is $>275 \mathrm{Ma}$ ) range between $191 \pm 8 \mathrm{Ma}$ and $75 \pm 5 \mathrm{Ma}$, indicating that significant thermal events affected the study area during that period. Thermal inversion supports two main cooling events that we attribute to a major uplift and denudation of the Variscan basement, consistent with widespread basement-derived siliciclastic rocks of similar ages: Late Jurassic/Early Cretaceous (ca. 150-145 Ma) and late Early Cretaceous (ca. $110 \mathrm{Ma}$ ). From the sedimentary record in the Lusitanian Basin and the new AFT data, we deduce that: (1) temperatures $>70-110^{\circ} \mathrm{C}$ affected west Iberia between ca. 190 and $150 \mathrm{Ma}$, which can be explained partly by a subsiding basement in both foot and hanging walls; (2) the main cooling event at ca. 150-145 Ma is interpreted as major rift flank uplift; (3) the ca. 110 Ma cooling event may be linked to the final evolution of the margin and onset of oceanic spreading. We infer that the AFT main cooling event at ca. 150-145 Ma reflects the break of the elastic core of the lithosphere (whole lithosphere failure = breakup) with significant rift shoulder uplift (end of Rift 1), which was followed by hyper-extension and mantle exhumation (Rift 2) and finally, by oceanic spreading (rift-to-drift) at ca. $110 \mathrm{Ma}$ (onset of Rift 3).

Keywords: breakup; rift-to-drift; rift flank uplift and denudation; Iberia-Newfoundland Atlantic opening; whole lithosphere failure; apatite fission track thermal history 
43

Breakup of the continental lithosphere (rift) and sea-floor spreading (drift) are two significant phases of the supercontinent cycle (Allen and Allen, 2005). Timing is crucial but may still be subject to debate in some key areas. The Newfoundland-Iberia rift system has been considered the archetype of a magma-poor rift (Boillot et al., 1980, 1995; Manatschal and Bernoulli,1999; Whitmarsh et al., 2001; Reston, 2009; Pereira et al., 2017) and its age of riftto-drift stage is subject to debate as there is still no agreement on the position and the ages of the magnetic anomalies. This is partially due to the existence of a diffuse continent ocean transition due to ultra-slow opening (Dean et al., 2000). There are three main views on its timing: Late Jurassic (160 Ma-145 Ma) to Early Cretaceous (>128 Ma) (e.g. Mauffret et al., 1989; Hiscott et al., 1990; Whitmarsh and Miles, 1995; Srivastava et al., 2000; Wilson et al., 2001; Russell and Whitmarsh, 2003; Tucholke et al., 2007), Early Cretaceous (ca. 112 Ma) (e.g. Driscoll et al., 1995), and spread over time (145-128 Ma and $112 \mathrm{Ma}$ ) (e.g. Péron-Pinvidic et al., 2007; Bronner et al., 2011). A strong argument has been put forward by Srivastava et al. (2000) in favour of an Upper Jurassic rift-to-drift stage in the south (rifting was diachronous along the strike, i.e. becoming younger as you move from south to north), because the oldest magnetic anomaly that has been found west of Iberia and in the Grand Banks of Canada is M20, i.e. ca. $147 \mathrm{Ma}$. Subsidence has been analysed to estimate the successive rift stages in western Iberia but has not brought decisive answers (e.g., Stapel et al., 1996; Rasmussen et al., 1998; Leinfelder and Wilson, 1998; Alves et al., 2002, 2009, 2018). Three rift phases have been recorded: Rift 1 (during the Late Triassic $>202$ Ma), Rift 2 (during most of the Jurassic, ca. 200 to $150 \mathrm{Ma}$ ) and Rift 3(at the end of the Jurassic, especially in the transition from the Jurassic to the Cretaceous, ca. $145 \mathrm{Ma}$ ). Additional data is required to clarify this issue.

If the concept of rift-to-drift is clear and well established as the moment of first creation of basaltic oceanic crust, the concept of breakup is unclear, and is often assumed to be equivalent to rift-to-drift. Breakup may also be the stage when one continental lithosphere becomes two separate plates, followed by hyper-extension and an intervening transition zone made up of exhumed mantle and intrusive gabbro and mafic dykes (Soares et al., 2012). To resolve this ambiguity, in this study we have used the mechanical definition of lithosphere (elastic in time scales of Ma; e.g. Burov and Diament, 1995) to consider that a lithospheric plate is broken (breakup moment) when its elastic core vanishes, i.e. its elastic thickness becomes zero. This corresponds to the concept of "whole lithosphere failure" (WLF) (e.g. Kusznir and 
Park, 1982; see also Marques and Podladchikov, 2009 and figure S1 in the supplementary material). Following this definition, we should see the effects of WLF on the vertical movements of rift shoulders (Beaumont et al., 1982; Weissel and Karner, 1989), encompassing the whole basin. Weissel and Karner (1989) suggested that rift flank uplift during extension may result from mechanical unloading of the lithosphere and a consequent isostatic rebound. This mechanism is preferred here as an alternative to explanations for rift flank uplift involving thermal processes and magmatic thickening of the crust, because we are studying a magmapoor rift.

The aim of this paper is to understand the behaviour of the rift shoulder, thus allowing us to deduce the age of WLF from rift shoulder uplift. We investigated this uplift, using lowtemperature thermochronology coupled with the onshore geological records. AFT thermochronology has long been used to detect upper crustal rock uplift and cooling, in particular on passive margins (e.g., Gallagher and Brown, 1997).

\section{Geological context and previous LTT results}

In western Iberia, the basement is mostly made up of pre-Variscan rocks which have been deformed, metamorphosed and intruded by granitoids during the Variscan orogeny in the late Palaeozoic (e.g., Quesada and Oliveira, 2019). The core of the orogen, known as the Central Iberian Zone, is mostly composed of plutonic rocks (granitoids), which is where most of the samples were collected. Immediately to the south lies the Ossa-Morena Zone, which is a major terrane accreted to the southern margin of the Central Iberian Zone (Quesada and Oliveira, 2019), and where we collected some samples from gabbro and granite. Available U-Pb data indicates that the sampled gabbro and various granites crystallized prior to $295 \mathrm{Ma}$ (Table 1, and references therein).

The Iberian margin has been considered to be a lower plate, magma-poor, hyperextended continental lithosphere, the structure of which is variable both across and along the strike (e.g., Péron-Pinvidic et al., 2007; Alves et al., 2009) across the strike (E-W) because of the distance to the rift shoulders (proximal and distal sedimentation and structure), and along the strike (NS) because rifting seems to have been diachronic, propagating from south to north (e.g. Whitmarsh and Miles, 1995; Tucholke et al., 2007; Alves et al., 2009). 
The sedimentary infilling can be summarized as follows. From the Late Triassic to the Late Cretaceous, fault-controlled regional subsidence lead to the deposition of a thick Mesozoic cover that reaches $>6 \mathrm{~km}$ in the deepest parts of the onshore LB (Wilson et al., 1989; Kullberg, 2000; FrogTech, 2012; Fig. 3). The master fault bounding the LB in its central-northern portion is the reactivated Porto-Tomar-Badajoz Fault (PTBF) striking N-S to NNW-SSE (PTBF, Fig. 1) from Porto to Tomar, and in its southern portion is the reactivated NNE-SSW late-Variscan fault system (Marques et al., 2002). In the early stages of rifting (Hettangian), with restricted salt-water circulation and which was dominated by evaporation, a thick evaporitic sequence was deposited, which reaches almost 3,000 m thickness in some places. During the Early and Middle Jurassic (ca. 201 to $164 \mathrm{Ma}$ ), marine deposits accumulated in the current onshore central-northern LB. Rocks are mostly marls, marly limestones and limestones. The early Late Jurassic (Oxfordian to early Kimmeridgian) is still marine (limestones and marls), but with intercalations of fine calcarenites. The late Kimmeridgian and Tithonian lie unconformably (ca. $20^{\circ}$ angular unconformity) on previous Jurassic rocks, and are mostly composed of calcarenites, calcarenites with limestone boulders, sandstones with mixed siliceous and calcareous boulders, and some intercalated marls. This late Upper Jurassic detrital carbonate sequence demonstrates that erosion was occurring within the LB, either by basin uplift or eustatic sea level change. The total thickness of the Jurassic in the central-northern LB, measured at the outcrop and in deep wells, is ca. 3,000 $\mathrm{m}$ (Rocha et al., 1981). Together with the Hettangian evaporites, the total thickness of the pre-Cretaceous sediments may be between 4,000 and 5,000 m. The Cretaceous initiates with the most prominent unconformity in the LB lie on deformed preCretaceous rocks (mostly Jurassic), where coarse and very coarse conglomerates, with siliceous clasts and boulders originated in the basement to the east. The conglomerates are overlain by siliceous sandstones, whose grain size decreases in the upper section (Trincão et al. 1989).

We have observed no Jurassic and Cretaceous sediments lying on the currently exposed Variscan basement east of the PTBF, except in a small area north of the western end of the thrust bounding the Serra da Estrela to the north (Fig. 1), and close to the eastern border of the LB. This small basin, the Lousã Basin, has deposits that include feldspathic sandstones from the Albian to the Late Campanian (Cunha, 1999).

Three main Mesozoic rifting stages have been considered in the literature for the on and offshore LB (see Fig. 2; e.g., Wilson et al., 1989; Rasmussen et al., 1998; Alves et al., 2002, 2006, 2009; Pereira and Alves, 2012): Rift 1 - Triassic (> $201 \mathrm{Ma}$ ); Rift 2 - Sinemurian-early 
Pliensbachian (ca. $190 \mathrm{Ma}$ ) and Wilson et al. (1989) suggests a single extensional event from Triassic to Callovian; Rift 3 - late Oxfordian (ca. $155 \mathrm{Ma}$ ). All of them indicate the progressive subsidence and deposition of marine sediments. The latter has been considered the main subsidence episode in the LB (Leinfelder and Wilson, 1998; Stapel et al., 1996; Alves et al., 2002), and the precursor of ocean spreading in the Tagus Abyssal Plain (Wilson et al., 1989). Pinheiro et al. (1992) suggested a Valanginian age (ca. $135 \mathrm{Ma}$ ) for the initiation of ocean spreading. Alternatively, the oldest magnetic anomaly in western Iberia may be M20 [Srivastava et al., 2000], which may indicate a late Tithonian age (ca. $147 \mathrm{Ma}$ ) for the rift-todrift stage in southwest Iberia. A Rift 4 event has been suggested (e.g. Alves et al., 2009), which lasted from the Jurassic/Cretaceous boundary to mid Lower Cretaceous. The onset of seafloor spreading between Iberia and Newfoundland has long been debated. Based on the first undisputed oceanic magnetic anomaly (M3), Whitmarsh and Miles (1995) suggested an age of ca. $128 \mathrm{Ma}$ for the rift-to-drift stage, whereas Tucholke et al. (2007) and Péron-Pinvidic et al. (2007) proposed a ca. 112 Ma age based on drilling results and seismic stratigraphic arguments.

Little thermochronological data is available to record the post-Variscan history of the basement in western Iberia. Pereira et al. (1998) presented AFT ages for two Variscan granites of the northern domain (Central Iberian zone) and four sandstones from different stratigraphic levels (Upper Carboniferous, Triassic, Upper Jurassic and Lower Cretaceous) from the LB, and concluded that there had been active erosion of the basement throughout the Jurassic and the Cretaceous, but the driving forces are not considered. Very little data is available for the southern domain (Ossa Morena Zone), but the data does confirm younger ages and significant cooling (112 to 70 Ma; Stapel 1999; Vázquez-Vílchez et al., 2015).

\section{Sampling and methodology}

Given the objective of analysing the vertical motion of the rift shoulder, we collected 17 samples of Variscan granites along transects in the basement east of the westward-dipping master bounding fault (footwall of the reactivated PTB shear zone as normal fault - PTBF), and one granitic sample included in a very coarse Triassic conglomerate in the LB (hanging wall of the PTBF). The sampled plutonic rocks include monzonite, granite, granodiorite and gabbro related to syn-tectonic and post-tectonic Variscan magmatic events. Granitic boulders (COI3) within conglomerates attributed to the Triassic were collected in Coimbra, in the hanging-wall 
of the master fault bounding the LB, very close to the contact with the Variscan basement.

AFT analysis was performed using the external detector method and zeta calibration (Hurford and Green, 1983) at the GEOPS laboratory (Université Paris Saclay). Classical mineral separation procedures were followed, and apatite grains were picked using a binocular microscope. Samples were then irradiated in the Garching facility of the Technische Universität München (Germany) with a fluence of $5 \times 10^{15} \mathrm{n} / \mathrm{cm}^{2}$. Etching conditions were $5 \mathrm{M} \mathrm{HNO}_{3}$ for 20 seconds at $20 \pm 0.5{ }^{\circ} \mathrm{C}$ for apatite crystals, and $40 \% \mathrm{HF}$ for 20 minutes at $20 \pm 1{ }^{\circ} \mathrm{C}$ for muscovite external detectors. Central ages were calculated using a $\zeta$-value for the dosimeter glass CN5 of $359 \pm 8$, calibrated by multiple analyses of IUGS apatite age standards (Durango and Fish Canyon). Only crystals with sections parallel to the $c$-axis were analysed. Confined track-lengths were measured using only TINTs (track-in-track) under a 100x dry objective with a digitizing tablet linked via a drawing tube attached to the microscope. The angle to the $c$-axis was measured for each track length, and Dpar values are available to determine the structural/chemical control of apatite on fission-track annealing (Carlson et al., 1999; Barbarand et al., 2003).

The thermal history was determined by QTQt modelling (Gallagher, 2012), which allows for the inverting of AFT data using a Markov chain Monte Carlo sampling method. The inversion code incorporates the multi-compositional fission-track annealing model (Ketcham et al., 2007). The modelling starts with an initial randomly chosen time-temperature path and set of kinetic parameters, for which a probability that the model fits the data is calculated, and the model with the highest probability is retained. This procedure is repeated many times (100 000 iterations were used in this study), providing many models with their associated probabilities that allow us to calculate statistical models, and ultimately the best-fit model.

\section{Results}

AFT ages in granites range between $75 \pm 4$ and $191 \pm 8$ Ma (Figs. 1 and 4; Table 1) with high homogeneity within samples (see radial plot distributions in the supplementary information, figures S2a-b-c). AFT ages are then much younger than the crystallization age of the granites (> $295 \mathrm{Ma}$; Table 1). This is consistent with old rocks being dated by a lowtemperature dating technique (AFT). They appear also younger than the ages measured for samples lying at the surface since Permo-Triassic times. The measured age variations can be 
grouped by geographical distribution of the samples considering (1) rapid change on three main units bounded by main faults, and (2) younger ages towards the north for samples located in the western and central units. Three units where FT ages are coherent have been defined and they are separated by main late-Variscan faults (Fig. 1): a western unit, west of the Chaves fault; a central unit between the Chaves and Vilariça faults; and an eastern unit located east of the Vilariça fault. The central unit is characterized by the oldest ages (137 \pm 8 to $191 \pm 8 \mathrm{Ma})$, with younger ages towards the north. The western unit is characterized by younger ages $(75 \pm 4$ to $157 \pm 8 \mathrm{Ma}$ ), but with similar even younger ages towards the north. The eastern unit displays young ages ( $78 \pm 4$ to $110 \pm 9 \mathrm{Ma})$, with two older ages (151 \pm 8 and $162 \pm 8 \mathrm{Ma})$. A sharp age transition is observed between the central and eastern units, across the main Vilariça fault. The same observation can be made over a short distance $(\sim 10 \mathrm{~km})$ across the Chaves fault, between sample AN (137 \pm 8$)$ located in the central unit and sample BAR $(75 \pm 4 \mathrm{Ma})$ in the western unit. The definition of the different units depends on the number and distribution of samples, but we are confident that the density of our sample size is enough to build a pertinent age distribution and identify different units. Samples from the southern domain (Ossa-Moreno Zone) have been considered separately, as they are far away from the other samples, but display similar young ages $(88 \pm 16$ and $97 \pm 7 \mathrm{Ma})$. All samples except sample $\mathrm{T}$ pass the chi-square test, indicating that a single age population exists for each sample. No relationship was found between AFT ages and current topographic elevation.

Mean horizontal confined track lengths in samples for which enough tracks have been measured (minimum 50, 13 samples) range between 12.0 and $12.8 \mu \mathrm{m}$, and $13.4 \mu \mathrm{m}$ for just only one sample (SCD, which also displays the oldest age) and have a unimodal distribution. The standard deviation of the mean length ranges between 1.3 and $1.8 \mu \mathrm{m}$, except for sample $\operatorname{SCD}(\mathrm{SD}=1.0 \mu \mathrm{m})$. All samples have similar Dpar $(1.4-1.7 \mu \mathrm{m})$, characteristics of apatite crystals with a high fluorine content.

\section{Thermal modelling}

Inverse modelling of the AFT data was produced for all samples. For most of the samples, two boxes have been input for initial thermal inversion at the beginning and the end: (1) The start of the low-temperature history at $300 \mathrm{Ma}$, and at a minimum temperature of $120{ }^{\circ} \mathrm{C}$ considering crystallization and cooling ages (Hildenbrand et al. 2021). The strict definition of a crystallization age is not necessary because FT ages are below $200 \mathrm{Ma}$ and crystallization ages are $>295 \mathrm{Ma}$ (Table 1). (2) At the surface (temperature of ca. $20^{\circ} \mathrm{C}$ ) at present-day (time 
$236=0 \mathrm{Ma}$ ). To the south of the central unit, near to the city of Coimbra (Fig. 1) and east of the PTBF, the presence of Aptian (Trincão et al., 1989) continental siliciclastic rocks are deposited unconformably on top of the basement, and it is here considered to be a geological constraint for samples SCD and NEL to be close to the surface before the Aptian.

Results of inverse modelling are presented for the different units, starting with the central unit where the presence of Lower Cretaceous sedimentary rocks unconformably on the Variscan basement helps to understand some possible scenarios.

\section{Central unit}

Sample SCD is the oldest in age $(191 \pm 8 \mathrm{Ma})$, and has the longest mean track length $(13.4 \pm 0.1 \mu \mathrm{m})$ with a narrow distribution (confined horizontal track-length histograms are available in figure S3 of the SI). Modelling shows that this sample underwent low temperatures $\left(<40^{\circ} \mathrm{C}\right)$ during the Mesozoic (Fig 5-A). Modelling of sample NEL, also close to the surface in the Aptian, produced a different trend, with a high temperature during the beginning of its history (Fig. 5-B). Sample VTA produced a non-indicative thermal history, the best fits corresponding to linear cooling from the starting point to the present-day. These contrasting thermal histories are not consistent with the small size of the area in which these samples outcrop, so begging for an alternative explanation is needed.

Whilst considering the thermal history of sample SCD, we tested thermal inversion for samples NEL and VTA assuming the presence of these samples at near surface temperatures $\left(20 \pm 10^{\circ} \mathrm{C}\right)$ during Triassic times. As expected from basin evolution, the temperature increased up to $\sim 90{ }^{\circ} \mathrm{C}$ during rifting after the Triassic, and then decreased as discussed in this work (Figs. 5-C and 5-D). The northernmost sample (AN) recorded a higher temperature $\left(\sim 100^{\circ} \mathrm{C}\right)$ that has erased the early history, and then underwent a decrease in temperature during the Cretaceous (Fig. 5-E). The thermal history obtained for samples NEL and VTA is very similar to the one obtained for sample COI3, which corresponds to granitic boulders in Triassic conglomerates outcropping currently in Coimbra, very close to the PTBF. After deposition, the temperature increased during most of the Jurassic to reach $\sim 100{ }^{\circ} \mathrm{C}$, followed by a cooling period during Cretaceous and Cainozoic times.

Modelling indicates that rocks from the Central Unit underwent post-Triassic heating up to $\sim 90-100{ }^{\circ} \mathrm{C}$, except for sample SCD for which the temperature is probably lower $\left(<50{ }^{\circ} \mathrm{C}\right)$. Cooling is not well understood, which may be due to partial annealing of most of the samples, 
in which tracks which formed before the temperature peak were partly preserved, thus blurring the thermal history. The signal is clearer for sample AN (where most of the tracks which formed prior to the temperature peak were erased) and cooling started at $\sim 160-150 \mathrm{Ma}$.

\section{Western unit}

Three samples (BAR, GRJ, ALH) with a minimum measured length of 50 tracks have been processed. All models are characterized by high temperatures during the Jurassic $(\sim 100$ ${ }^{\circ} \mathrm{C}$ ), capable of resetting the FT system. Cooling occurred from $\sim 160-150 \mathrm{Ma}$ (ALH) or later at 130-110 Ma (Fig. 6). Although less constrained, a similar thermal history is obtained for sample SVG. Cooling appears complex for sample BAR with two episodes: Lower (in common with the other samples) and beginning in the Upper Cretaceous and Neogene. This may be due to the relatively low MTL $(12.0 \pm 0.1 \mu \mathrm{m})$, implying that the sample stayed at relatively high temperature for longer.

\section{Eastern unit}

Similarl to the modelling of samples from the western unit, modelling of samples MTG1, SRT and CST from the eastern unit shows the existence of a high temperature $\left(\sim 100^{\circ} \mathrm{C}\right)$ during the Jurassic, which has fully reset the former thermal history of the samples (Fig. 7). Peak temperature was followed by cooling that started at $\sim 120-110 \mathrm{Ma}$. Cooling does not appear to be linear for samples MTG1 and SRT, with faster rates during the Neogene. Modelling of samples AC and T, which have older FT ages, is not indicative, as best fits correspond to linear cooling between $300 \mathrm{Ma}$ and present-day. The addition of a constraint assuming the presence of sample $\mathrm{T}$ close to the surface during the Triassic generates a history compatible with the other samples and shows that the temperature was higher during the Jurassic.

Fission-track data and models support overall (except samples SCD and T) high temperatures during the Jurassic and cooling during Late Jurassic and Cretaceous times with cooling starting at $\sim 160-150$ Ma or $\sim 120-110 \mathrm{Ma}$.

\section{Discussion}




\subsection{Origin of post-Variscan high $\left(\sim 100^{\circ} \mathrm{C}\right)$ temperatures}

Fission-track data and thermal models indicate overall high temperatures during the Jurassic, except for samples SCD and T. Most of the samples are basement rocks that may have risen towards the surface after the Jurassic, but this explanation ignores the fact that some samples were already close to the surface at the end of the Triassic. Three alternative processes are generally considered to explain the temperature increase and are discussed below: (1) heat introduced into the system by magmatic activity, (2) circulation of thermal fluids in disequilibrium with the host rock, and (3) burial.

1. Three magmatic events have been described on the onshore sector of the West Iberian Margin: the first event was at the Triassic-Jurassic transition ( $200 \mathrm{Ma})$, the so-called Central Atlantic Magmatic Province (CAMP) of the Atlantic large igneous province, which has generated large volumes of basalts that have affected the whole Atlantic margin (e.g. Marzoli et al., 1999). The ca. $600 \mathrm{~km}$ long Messejana-Placencia dyke crossing Iberia from SW to NE is significant evidence of this episode, which may have significantly affected the neighbouring basement temperature (Dunn et al., 1998). Except for sample SCD, which shows rapid cooling initiated close to $\sim 200 \mathrm{Ma}$, all samples have recorded a high temperature during the Jurassic, i.e. long after the CAMP event. If we assume that the origin of these temperatures is related to the CAMP, we also have to consider a protracted and pervasive period of heating too. Given that no evidence of pervasive heating has been reported, it thus appears difficult to have a near-surface temperature of $\sim 100^{\circ} \mathrm{C}$ in such a large continental area and over such a long period of time, at least for the entire Jurassic. A second thermal event has been described around 145 Ma (Ferreira and Macedo, 1983; Grange et al., 2008; Mata et al., 2015), but it corresponds to low volumes of igneous intrusions restricted to dykes far from the basement studied here, and it is therefore unable to reset the FT ages. A third, Upper Cretaceous (ca. 85 to 75 Ma), event (Rui Miranda et al., 2009; Grange et al., 2010) is quite voluminous, but very localised west and south of Lisbon (Sintra, Sines and Monchique igneous massifs), and cannot have affected the whole study area at the periods of interest in this article.

2. Circulation of hot fluids might also be considered, but it appears difficult to imagine and model fluid circulation on such a large area across rocks with low permeability without any robust driving forces. Numerous mineralized sites have been recognized in the Central Iberian Zone and three periods for mineralization have been reported (Tornos et al. 2000): 
late-Variscan (295-275 Ma), Mesozoic (150 and $100 \mathrm{Ma}$ ) and Alpine (20 Ma), with the late-

3. Temperatures higher than surface temperature can be explained by two different models considering granite rock samples or sedimentary Triassic rocks. For the Triassic conglomerates, heating to $90 \pm 10{ }^{\circ} \mathrm{C}$ must be by burial of Triassic deposits below thick Jurassic ones. For the samples collected in the granitic basement, the temperature may be explained in two different ways: (i) The sampled granites were at the surface in the Triassic and were buried together with the Triassic sediments (Fig. 8A and 8B). Given the geographical distribution of the samples, this would mean that a much wider Jurassic basin should have formed extending much further east than the currently known LB boundary. Wilson et al. (1989) also noted the absence on the eastern basin margin of significant siliciclastic sands in the Lower and Middle Jurassic formations, and suggested that carbonate deposition probably extended far into the interior of Iberia. However, there are no known Jurassic sediments on top of the Variscan basement, and no detrital deposits are known in the LB showing evidence of erosion of all the possible thick Jurassic sediments covering the basement to the east. This assumption may however be true for the central unit samples where the thermal histories are similar to that of the Triassic sample and have relatively old FT ages (SCD, NEL, VTA). Consideration of this assumption on a wider scale has yet to be done. (ii) The sampled granites were at a certain depth (equivalent to ca. $100{ }^{\circ} \mathrm{C}$ ) at the time of deposition of the Triassic conglomerate, the upper section of the granitic massif being at the surface to feed erosion (Fig. 8A). During the Jurassic, the Triassic conglomerate was buried below thick Jurassic sediments, and along the master bounding fault at a similar depth to that of the basement samples were (Fig. 8B). Later, at ca. $150 \mathrm{Ma}$, footwall uplift occurred differentially along the master bounding faults (Porto-Tomar-Badajoz, Chaves and Vilariça faults) to produce a major rift shoulder uplift that exhumed the buried rocks that we sampled in both Triassic conglomerates and the granitic basement (Fig. 8C). Consequent erosion brought the LB with thick and coarse siliciclastic sediments. This second scenario is 
consistent with geological evidence and the fact that AFT data which shows a similar story for granites in the basement and in the Triassic conglomerates. Our data includes only one Triassic conglomerate, but some similar data has been measured in the LB: AFT ages of $169 \pm 8,204 \pm 9,132 \pm 16$ and $147 \pm 10$ Ma have been measured in four sandstones from different stratigraphic levels, respectively Upper Carboniferous, Triassic, Upper Jurassic and Lower Cretaceous (Pereira et al., 1998). These ages also show that Upper Jurassic and Lower Cretaceous sediments were not significantly affected by annealing in the LB.

We suggest that differential burial of the Triassic (subsiding hanging wall) and the Variscan basement (stable footwall with most of the granite samples at a certain depth) and the later simultaneous uplift of both is the most plausible explanation for the high temperatures recorded by FT data.

\subsection{Age and mechanisms of Mesozoic cooling}

Two phases for the beginning of cooling have been defined by the thermal modelling of different samples: 160-150 Ma from the western and central units and 120-110 Ma from the eastern unit. The offset between these two phases can be interpreted in two different ways. Two uplift episodes separated by $\sim 40 \mathrm{Ma}$, or a single, slower, uplift episode. In the latter case, the age offset would correspond to the duration required for the eastern unit to cross the isotherms, with samples from this unit being originally much deeper in the crust than samples from the western and central units. Coincidently, these ages correspond to the limits of the interval ascribed in the literature to rift-to-drift - 160 to $110 \mathrm{Ma}$. FT ages are younger towards the north and this is consistent with the proposed diachronism for rifting in western Iberia. Jagoutz et al. (2007) argued that ca. $110 \mathrm{Ma}$ is the age of the rift-to-drift stage, i.e. it is the age at which new oceanic crust started to form. Our AFT data also indicates cooling at this age, and therefore we agree with Jagoutz et al.'s (2007) interpretation that ca. 110 Ma marks the rift-to-drift stage. Timing of the uplift in southern Portugal is different from northern Portugal as the probable age is Late Cretaceous to early Palaeocene. Fernandez et al. (2013) showed that peak temperatures were attained in the Mesozoic rocks during the latest Cretaceous-early Palaeocene times (Fernandez et al., 2013). Their modelled palaeotemperatures suggest also that the Jurassic sedimentary rocks entered the oil-window at the beginning of the Cretaceous, with peak oil generation in the Late Cretaceous time. 


\subsection{Consistency between new and previous data/interpretations}

Three to four rift phases have been proposed for the LB (see Fig. 2; e.g., Wilson et al., 1989; Rasmussen et al., 1998; Alves et al., 2009). We do not discard the hypothesis that minor rift pulses may have existed, like Rifts 2 and 3 of Rasmussen et al. (1998) and Alves et al. (2002, 2006, 2009), or extensional event two of Wilson et al. (1989). However, from the main stratigraphic trends in the geological record and their geodynamic meaning, we do not see the need for three or four rift phases. For instance, Rifts 1 and 2 are separated by a gap in which the thick Hettangian evaporites were deposited (e.g., Rasmussen et al., 1998; Alves et al., 2002, 2006, 2009; Alves and Cunha, 2018). Wilson et al. (1989) also did not find arguments in favour of two rift stages for the period Triassic-Callovian. Deposition of marly limestones and limestones marks unrestricted opening to sea water, thus again indicating continued subsidence until the late Upper Jurassic (ca. $160 \mathrm{Ma}$ ). This continued subsidence is consistent with the modelled heating event between 190 and $160 \mathrm{Ma}$, which was suddenly interrupted ca. 150-145 Ma ago, as attested by the major Jurassic/Cretaceous unconformity with deposition of thick siliciclastic sediments derived from the uplifted rift shoulder.

Based on large unconformities, we suggest that there were only two continental rift stages, one (Rift 1) from the Late Triassic to the latest Jurassic, and the other (Rift 2) from the Jurassic/Cretaceous boundary till the first formation of the basaltic oceanic crust. This rift-todrift stage marks the shift from continental (Rift 2) to oceanic rifting, which can be considered Rift 3 lasting until present-day. We note that, despite disagreements regarding rift stages, there is a major coincidence between our AFT cooling age of ca. 150-145 Ma age (Rift 1 to Rift 2 boundary) and the age of the base of Breakup Sequence A (ca. $150 \mathrm{Ma}$ ) of Alves and Cunha (2018), or the age of shifting from pre-tectonic to syn-tectonic sedimentation (ca. $145 \mathrm{Ma}$ ) of Sutra et al. (2013).

Boillot et al. (1980) showed that the lithosphere underwent drastic thinning from the Tithonian to the Barremian, which finally led to the unroofing of the subcontinental mantle in the distal margin to form the COT. Boillot et al. (1988) suggested that tectonic unroofing and serpentinization of mantle rocks occurred just before seafloor spreading started at $114 \mathrm{Ma}$ ago in this part of the North Atlantic, which is also consistent with the $110 \mathrm{Ma}$ age proposed for the rift-to-drift stage. In order for the lithosphere to undergo major thinning, its elastic core must have vanished, thus allowing for whole lithosphere failure (WLF). Therefore, WLF must precede hyper-extension and mantle exhumation, which means that there is no inconsistency between our new data (WLF age) and previous data and ages. Rift 2 was not as simple as Rift 
1 (continued subsidence) and led to a complexity that characterizes the rift in western Iberia, which has attracted so much investment in research over several decades. When the elastic core of the continental lithosphere broke (WLF stage between Rifts 1 and 2), three main geodynamic reconfigurations occurred during Rift 2: (1) the rift shoulder underwent a major uplift, (2) the continental viscous "lithosphere" was hyper-extended, which finally led to (3) unroofing and mantle exhumation.

Jagoutz et al. (2007) concluded that the rift-to-drift stage is not a well-defined event, but rather a transitional process occurring over a period of time lasting from ca. $128 \mathrm{Ma}$ (oldest age of intrusive gabbro) to ca. $113 \mathrm{Ma}$ in the rift in western Iberia. These ages are consistent with the AFT data reported here, which indicates a rift-to-drift stage at around $110 \mathrm{Ma}$. Given that $128 \mathrm{Ma}$ is the minimum age of mantle exhumation, then hyper-extension and mantle exhumation must have taken place before $128 \mathrm{Ma}$. In the Iberia Abyssal Plain, which roughly corresponds to the area of interest in this study, mantle exhumation likely started at ca. $136 \mathrm{Ma}$ (Valanginian) (e.g., Manatschal et al. 2001; Sutra et al. 2013). This is consistent with the age of 150-145 Ma for WLF. Wilson et al. (2001) suggested that the maximum age of the deformation which led to continental breakup in the Newfoundland-Iberia Rift is given by tilted Tithonian sediments (ca. 152-145 Ma) deposited over thinned continental crust drilled at ODP Sites 901, 1065 and 1069. This is also consistent with the age we propose for breakup. More recently, Alves et al. (2009) and Alves and Cunha (2018), based on the concept of breakup unconformity, suggested early Berriasian (ca. 145-140 Ma) for the age of continental breakup, which again is consistent with our new data for WLF.

The new AFT data shows younging of the cooling ages to the north in the western and central units, in agreement with the diachronous evolution of the rift proposed in previous studies (e.g. Whitmarsh and Miles, 1995; Tucholke et al., 2007; Alves et al., 2009). Thermochronology data also show that the margin remained relatively stable after the CentralNorth Atlantic opening and that minor Alpine deformation is recorded during Tertiary (erosion $<1 \mathrm{~km}$ ), in contrast to central Iberia where vertical movements are significant.

\subsection{Regional implications}

From the new AFT data and the geological context, we infer the following evolution of the eastern margin of the Newfoundland-Iberia Rift (carton in Fig. 9):

460 (1) Rift 1 - first stage lasting from the Triassic until ca. $150 \mathrm{Ma}$, which corresponds to a general 
subsidence of the margin that is responsible for the initial heating stage in AFT data (Fig. 9A). Vertical movements were accommodated along lithospheric scale shear zones inherited from the Variscan orogeny.

(2) Cooling at ca. $150 \mathrm{Ma}$ - this stage is characterized by a general uplift of the margin and associated major erosional angular unconformity (Fig. 9B). The Western and Central units in the Variscan basement and eastern margin of the Lusitanian Basin were eroded as indicated by cooling of the samples. The critical change in sediment nature, from carbonate dominated sediments to coarse siliciclastic rocks, also attests to the uplift of the margin. This uplift seems to have been generalised to the entire Lusitanian Basin, as attested by the thick siliciclastic sediments in the Alentejo Basin (Alves et al., 2002), which diachronously progressed northwards so covering the entire Iberian margin both on and offshore.

(3) Rift 2 - this stage is bracketed between ca. 145 and $110 \mathrm{Ma}$ (Fig. 9C), and mostly corresponds to the period of hyper-extension and of the margin and consequent mantle upwelling. In the Iberia Abyssal Plain, which roughly corresponds to the area of interest in this study, mantle exhumation likely started at ca. $136 \mathrm{Ma}$ (Valanginian) (e.g., Manatschal et al. 2001; Sutra et al. 2013). The Eastern Unit in the Variscan basement was effectively eroded and the whole Variscan basement knew vertical movements, as inferred from the AFT data.

(4) Rift 3 - this stage is bracketed between ca. 110 Ma and present-day (Fig. 9C). Rift 2 of the continental rifting process came to an end with the onset of oceanic spreading (oceanic rifting), which occurred in the late Early Cretaceous (ca. $110 \mathrm{Ma}$ ) according to the new AFT data. The general trend of the sedimentation was upward finning during most of Rift 2, but the Aptian-Albian was again coarse silicic sandstones (Rasmussen et al., 1998; Wilson et al., 2001), from which we infer relatively high topography of the basement east of the Porto-Tomar Fault around 120-110 Ma that could be responsible for the AFT cooling age at ca. $110 \mathrm{Ma}$.

\section{Conclusions}

Based on geological data and the new AFT results, we infer the following geodynamic evolution of the Newfoundland-Iberia Rift in its eastern margin (western Iberia) (Fig. 9): (1) 
493 Rift 1 (>200 to ca. $150 \mathrm{Ma}$ ) - slow and continued subsidence from Upper Triassic to uppermost Jurassic (Kimmeridgian); (2) Breakup (150-145 Ma) - whole lithosphere failure by vanishing of its elastic core, with consequent major rift shoulder uplift and formation of a basin-wide erosional unconformity followed by deposition of thick siliciclastic rocks in the subsequent rifting stage; (3) Rift 2 (ca. 145 to $110 \mathrm{Ma}$ ) - without elastic resistance, the viscous "lithosphere" could be hyper-extended, which allowed for unroofing and mantle exhumation after ca. $136 \mathrm{Ma}$; (4) Rift-to-drift (ca. $110 \mathrm{Ma}$ ) - rise of the asthenosphere to shallow depth and first formation of basaltic oceanic crust, thus marking the transition from continental to oceanic rifting; (5) Rift 3 (ca. 110 Ma to present-day) - oceanic spreading with development of the MidAtlantic Ridge.

Contrary to previous work, we distinguish between breakup (whole lithosphere failure) and rift-to-drift (onset of oceanic spreading) and attribute an age to each of the stages based on the new AFT data: breakup at ca. $150 \mathrm{Ma}$ and rift-to-drift at ca. $110 \mathrm{Ma}$, with an intervening stage of hyper-extension.

Acknowledgements

This is a contribution from project GOLD (PTDC/GEO-GEO/2446/2012) funded by FCT Portugal. The quality of this manuscript has greatly benefited from the constructive and thorough reviews by Matthias Bernet and an anonymous reviewer, and by Editor Philippe Agard. 
Allen, P.A. \& Allen, J.R. 2005. Basin Analysis: Principles and Applications. Blackwell, Oxford.

Alves, T.M., Cunha, T.A., 2018. A phase of transient subsidence, sediment bypass and deposition of regressive-transgressive cycles during the breakup of Iberia and Newfoundland. Earth Planet. Sci Letters 484, 168-183.

Alves, T.M., Gawthorpe, R., Hunt, D.H., Monteiro, J.H., 2002. Jurassic tectono-sedimentary evolution of the Northern Lusitanian Basin (offshore Portugal). Mar. Pet. Geol. 19, 727754.

Alves, T.M., Moita, C., Cunha, T., Monteiro, J.H., Pinheiro, L., 2006. Meso-Cenozoic evolution of North-Atlantic continental slope basins: the Peniche Basin, Western Iberian margin. AAPG Bull. 90, 31-60.

Alves, T.M., Moita, C., Cunha, T., Ullnaess, M., Myklebust, R., Monteiro, J.H., Manuppella, G. 2009. Diachronous evolution of Late Jurassic-Cretaceous continental rifting in the northeast Atlantic (west Iberian margin). Tectonics 28, TC4003, doi: $10.1029 / 2008$ TC002337.

Antunes, I.M.H.R, Neiva, A.M.R, Silva, M.M.V.G, Corfu, F., 2008. Geochemistry of S-type granitic rocks from the reversely zoned Castelo Branco pluton (central Portugal). Lithos 103, $3,445-465$.

Azerêdo, A.C., 2007. Formal lithostratigraphy of the Lower and Middle Jurassic from the Maciço Calcário Estremenho (Lusitanian Basin). Comunicações Geológicas 94, 29-51.

Barbarand, J., Carter, A., Wood, I., Hurford, T. 2003. Compositional and structural control of fission-track annealing in apatite, Chemical Geology 198, 107-137.

Beaumont, C., Keen, C.E., Boutillier, R. 1982. On the evolution of rifted continental margins: comparison of models and observations for the Nova Scotia margin, Geophys. J.R. Astron. Soc. $70,667-715$.

Boillot, G., Beslier, M.O., Girardeau, J. 1995. Nature, structure and evolution of the oceancontinent boundary: the lesson of the West Galicia Margin (Spain). In: Banda, E., Torné, M. \& Talwani, M. (eds) Rifted Ocean-Continent Boundaries. Kluwer, Dordrecht, 219-229.

546 Boillot, G., Grimaud, S., Mauffret, A., Mougenot, D., Kornprobst, J., Mergoil-Daniel, J., 
Torrent, G., 1980. Ocean-continent boundary off the Iberian margin: a serpentinite diapir west of the Galicia Bank. Earth Planet. Sci. Lett. 48, 23-34.

Boillot, G., Winterer, E.L., Meyer, A.W., and Shipboard Scientific party, 1988. Proceedings ODP, Leg 103 Scientific Results. Ocean Drilling Program, Government Printing Office, Washington D.C., College Station, Texas.

Bronner, A., Sauter, D., Manatschal, G., Péron-Pinvidic, G. Munschy, M., 2011. Magmatic breakup as an explanation for magnetic anomalies at magma-poor rifted margins. Nat. Geosci. 4, 549-553. doi:10.1038/ngeo1201.

Burov, E.B., Diament, M.T., 1995. The effective elastic thickness (Te) of continental lithosphere:What does it really mean? Journal of Geophysical Research, 100, 3905-3927.

Carlson, W.D., Donelick, R.A., Ketcham, R.A. 1999. Variability of apatite fission-track annealing kinetics: I. Experimental results, American Mineralogist, 84, 1213-1223.

Cunha, P.P., 1999. Unidades litostratigráficas do Terciário na região de Miranda do CorvoViseu (Bacia do Mondego, Portugal). Comum. Inst. Geol. e Mineiro 86, 143-196.

Dean, S.M., Minshull, T.A., Whitmarsh, R.B., Louden, K., 2000. Deep structure of the ocean continent transition in the southern Iberia Abyssal Plain from seismic refraction profiles: II The IAM-9 transect at 40²0 N. J. Geophys. Res. 105, 5859-5886.

Dias, G., Leterrier, J., Mendes, A., Simoes, P.P., Bertrand, J.M., 1998. U-Pb zircon and monazite geochronology of postcollisional Hercynian granitoids from the Central Iberian Zone (Northern Portugal). Lithos 45, 349- 369.

Driscoll, N.W., Hogg, J.R., Christie-Blick, N., Karner, G.D., 1995. Extensional tectonics in the Jeanne d'Arc Basin, offshore Newfoundland: implications for the timing of break-up between Grand Banks and Iberia. In: Scrutton, R.A., Stoker, M.S., Shimmield, G.B., Tudhope, A.W. (Eds.), The Tectonics, Sedimentation and Palaeogeography of the North Atlantic Region. Geological Society Special Publication, London, pp. 1-28.

Dunn, A.M., Reynolds, P.H., Clarke, D.B., Ugidos, J.M. 1998. A comparison of the age and composition of the Shelburne Dyke, Nova Scotia, and the Messejana Dyke, Spain. Can. J. Earth Sci. 35, 1110-1115.

Ferreira, M.P., Macedo, C.R., 1983. Igneous rocks in the diapiric areas of the western Portuguese border: the $\mathrm{K}-\mathrm{Ar}$ ages and settings of the Upper Jurassic suite. Memórias e Notícias da Universidade de Coimbra 96, pp. 159-181. 
578 FrOGTech 2012. Report compiled for Mohave Oil and Gas Corporation.

Galbraith R.F., Laslett G.M., 1993. Statistical models for mixed fission track ages. Nucl. Tracks Radiat. Meas. 21, 4, 459-470.

Gallagher K., Brown R. 1997. The onshore record of passive margin evolution. Journal of the Geological Society, London, 154, 451-457.

Gallagher, K. 2012. Transdimensional inverse thermal history modelling for quantitative thermochronology, JGR, 117 (B02408), 16.

Grange, M., Scharer, U., Cornen, G., Girardeau, J., 2008. First alkaline magmatism during Iberia-Newfoundland rifting. Terra Nova 20, 494-503.

Grange, M., Scharer, U., Merle, R., Girardeau J., Cornen G. 2010. Plume-Lithosphere Interaction during Migration of Cretaceous Alkaline Magmatism in SW Portugal: Evidence from U-Pb Ages and Pb-Sr-Hf Isotopes. Journal of Petrology 51, 5, 1143-1170.

Hildenbrand, A., Marques, F.O., Quidelleur X., Noronha, F., 2021. Exhumation history of the Variscan orogen in western Iberia as inferred from new $\mathrm{K}-\mathrm{Ar}$ and ${ }^{40} \mathrm{Ar} /{ }^{39} \mathrm{Ar}$ data on granites from Portugal. Tectonophysics.

Hiscott, R.N., Wilson, R.C.L., Gradstein, F.M., Pujalte, V., García-Mondéjar, J., Boudreau, R.R., Wishart, H.A.1990. Comparative stratigraphy and subsidence history of Mesozoic rift basins of North Atlantic. The American Association of Petroleum Geologists Bulletin 74, 1, $60-76$.

Hurford, A.J., Green, P.F. 1983. The zeta age calibration of fission-track dating, Chemical Geology: Isotope Geoscience section 1, 285-137.

Jagoutz, O., Müntener, O., Manatschal, G., Rubatto, R., Péron-Pinvidic, G., Turrin B.D., Villa, I.M., 2007. The rift-to-drift transition in the North Atlantic: A stuttering start of the MORB machine? Geology 35, 12, 1087-1090.

Ketcham, R.A., Carter, A., Donelick, R.A., Barbarand, J., Hurford, A.J. 2007. Improved modelling of fission-track annealing in apatite. American Mineralogist 92, 5-6, 799-810.

Kullberg, J.C.R., 2000. Evolução Tectónica Mesozóica da Bacia Lusitaniana. PhD Thesis, Univ. Lisboa, p. 280.

Kusznir, N.J., Park, R.G. 1982. Intraplate lithosphere strength and heat flow. Nature, 299, 540542. 
Leinfelder, R.R., Wilson, R.C.L., (1998). Third order sequences in an Upper Jurassic rift-related second-order sequence, central Lusitanian Basin, Portugal, in Mesozoic and Cenozoic Sequence Stratigraphy of European Basins, edited by P.C. Graciansky et al., Spec. Publ. SEPM Soc. Sediment., 60, 507-525.

Lima, S.M., Corfu, F., Neiva, A.M.R., Ramos, J.M.F., 2012. Dissecting complex magmatic processes: an in-depth U-Pb study of the Pavia Pluton, Ossa-Morena Zone, Portugal. J. Petrol. 53, 1887-1911.

Manatschal, G., Bernoulli, D., 1999. Architecture and tectonic evolution of non-volcanic margins: Present day Galicia and ancient Adria. Tectonics 18, 1099 - 1119, doi:10.1029/1999TC900041.

Manatschal, G., Froitzheim, N., Rubenach, M., Turrin, B.D., 2001. The role of detachment faulting in the formation of an ocean-continent transition: Insights from the Iberia Abyssal Plain, in Non-Volcanic Rifting of Continental Margins: A Comparison of Evidence From Land and Sea, vol. 187, edited by R. C. L. Wilson et al., pp. 405-428, Geol. Soc. of London Special Publications.

Marques, F.O., Podladchikov, Y.Y., 2009. A thin elastic core can control large-scale patterns of lithosphere shortening. Earth Planet. Sci. Lett 277, 80-85.

Marques, F.O., Mateus A., Tassinari C., 2002. The Late-Variscan fault network in centralnorthern Portugal (NW Iberia): a re-evaluation. Tectonophysics 359, 255-270.

Marzoli, A., Renne, P.R., Piccirillo, E.M., Ernesto, M., Bellieni, G., de Min, A. 1999. 628 "Extensive 200 million-year-old continental flood basalts of the central Atlantic magmatic 629 province". Science 284 (5414): 616-618.

630 Mata, J.M., Alves, C.F., Martins, L., Miranda, R., Madeira, J., Pimentel, N., Martins, S., 631 Azevedo, M.R., Youbi, N., De Min, A., Almeida, I.M., Bensalah, M.K., Terrinha, P., 2015. $63240 \mathrm{Ar} / 39 \mathrm{Ar}$ ages and petrogenesis of the West Iberian Margin onshore magmatism at the 633 Jurassic-Cretaceous transition: Geodynamic implications and assessment of open-system 634 processes involving saline materials. Lithos 236-237, 156-172.

635 Mauffret, A., Mougenot, D., Miles, P.R., Malod, J.A. 1989. Cenozoic deformation and 636 Mesozoic abandoned spreading centre in the Tagus Abyssal plain (west of Portugal): Results 637 of a multichannel seismic survey. Canadian Journal of Earth Sciences 26, 1101-1123.

638 Neiva, A.M.R., Williams, I.S., Ramos, J.M.F.,Gomes, M.E.P., Silva, M.M.V.G., Antunes, 
I.M.H.R., 2009. Geochemical and isotopic constraints on the petrogenesis of Early Ordovician granodiorite and Variscan two-mica granites from the Gouveia area, central Portugal. Lithos 111, 186-202.

Neiva, A.M.R., Williams, I.S., Lima, S.M., Teixeira, R.J.S., 2012. U-Pb and ${ }^{39} \mathrm{Ar} /{ }^{40} \mathrm{Ar}$ data constraining the ages of the source, emplacement and recrystallization/cooling events from late- to post-D3 Variscan granites of the Gouveia area, central Portugal. Lithos 153, 72-83.

Nirrengarten, M., Manatschal, G., Tugend, J., Kusznir, N.J., Sauter, D., 2017. Nature and origin of the J-magnetic anomaly offshore Iberia-Newfoundland: implications for plate reconstructions. Terra Nova 29, 20-28. https://doi.org/10.1111/ter.12240

Pereira, R., Alves, T.M., 2012. Tectono-stratigraphic signature of multiphased rifting on divergent margins (deep-offshore Southwest Iberia, North Atlantic). Tectonics 31, 1-21. https://doi.org/10.1029/2011TC003001

Pereira, R., Alves, T.M., Mata, J., 2017. Alternating crustal architecture in West Iberia: a review of its significance in the context of NE Atlantic rifting. J. Geol. Soc. London. 174, 522-540. https://doi.org/https://doi.org/10.1144/jgs2016-050

Pereira, A.J.S.C, Carter, A., Hurford, A.J., Neves, L.J.P.F., Godinho, M.M., 1998. Evidence for the unroofing history of Hercynian granitoids in central Portugal derived from Late Palaeozoic and Mesozoic sedimentary zircons. In P. van den Haute and F. de Corte (eds) Advances in fission-track geochronology, Kluwer Academic Publishers, 173-186.

Péron-Pinvidic, G., Manatschal, G., Minshull, T.A., Sawyer, D.S., 2007. Tectonosedimentary evolution of the deep Iberia-Newfoundland margins: Evidence for a complex breakup history. Tectonics 26, TC2011, doi:10.1029/2006TC001970.

Pin, C., Fonseca, P.E., Paquette, J., Castro, P., Matte, P., 2008. The ca. 350 Ma Beja Igneous Complex: a record of transcurrent slab break-off in the Southern Iberia Variscan Belt? Tectonophysics 461, 356-377, 10.1016/j.tecto.2008.06.001

Pinheiro, L.M., Whitmarsh, R.B., Miles, P.R., 1992. The ocean-continent transition off the western continental margin off Iberia. Part II. Crustal structure in the Tagus Abyssal Plain. Geophys. J. Int. 109, $106-124$.

Quesada, C., Oliveira, J.T., 2019. The Geology of Iberia: A geodynamic approach. Volume 2: The Variscan cycle. "Regional Geology Reviews, Quesada, C., Oliveira, J.T. Editors; Simancas, J.F. volume coordinator. Springer Nature Switzerland, 544 pp. 
Rasmussen, E. S., Lomholt, S., Andersen, C., \& Vejbæk, O. V. (1998). Aspects of the structural evolution of the Lusitanian Basin in Portugal and the shelf and slope area offshore Portugal. Tectonophysics 300, 199-255.

Reston, T.J., 2009. The structure, evolution and symmetry of the magma-poor rifted margins of the North and Central Atlantic: A synthesis. Tectonophysics 468, 6-27.

Rocha, R., Manuppella, G., Mouterde, R., Ruget, C., Zbyszewski, G., 1981. Notícia explicativa da Folha 19-C, Figueira da Foz. Carta geológica de Portugal, escala 1:50,000, Serviços Geológicos de Portugal, 126 pp.

Rui Miranda, R., Valadares, V., Terrinha, P., Mata, J., do Rosário Azevedo M, Gaspar, M., Kullberg, J.C., Ribeiro, C 2009. Age constraints on the Late Cretaceous alkaline magmatism on the West Iberian Margin. Cretaceous Research 30, 575-586.

Russell, SM, Whitmarsh, RB 2003. Magmatism at the west Iberia non-volcanic rifted continental margin: Evidence from analyses of magnetic anomalies. Geophys Journal International 154: 706-730. doi:10.1046/j.1365-246X.2003.01999.

Soares, D. M., Alves, T. M., \& Terrinha, P. 2012. The breakup sequence and associated lithospheric breakup surface: Their significance in the context of rifted continental margins (West Iberia and Newfoundland margins, North Atlantic). Earth and Planetary Science Letters, 355, 311-326. https://doi.org/10.1016/j.epsl.2012.08.036.

Solá, A.R., Williams, I.S., Neiva, A.M.R., Ribeiro, L.M., 2009. U-Th-Pb SHRIMP ages and oxygen isotope composition of zircon from two contrasting late Variscan granitoids, NisaAlbuquerque Batholith, SW Iberian Massif: petrologic and regional implications. Lithos 111, 156-167, 10.1016/j.lithos.2009.03.045

Srivastava, S.P., Sibuet, J.C., Cande, S, Roest, W.R., Reid, I.D., 2000. Magnetic evidence for slow seafloor spreading during the formation of the Newfoundland and Iberian margins. Earth Planet. Sci. Lett. 182, 61-76.

Stapel, G., 1999. The nature of isostasy in western Iberia (PhD Thesis). Vrije Univ, Amsterdam, $148 \mathrm{p}$.

Stapel, G., Cloetingh, S., Pronk, B., 1996. Quantitative subsidence analysis of the Mesozoic evolution of the Lusitanian basin (western Iberian margin). Tectonophysics 266, 493-507.

Sutra, E., Manatschal, G., Mohn, G., Unternehr, P., 2013. Quantification and restoration of extensional deformation along the Western Iberia and Newfoundland rifted margins, 
Geochem. Geophys. Geosyst., 14, 2575-2597.

Tornos, F., Delgado, A., Casquet, C., Galindo, C. 2000. 300 Million years of episodic hydrothermal activity: stable isotope evidence from hydrothermal rocks of the Eastern Iberian Central System. Mineral. Deposita 35, 551-569. https://doi.org/10.1007/ s001260050261

Trincão, P., Pena dos Reis, R., Pais, J., Proença Cunha, P., 1989. Palinomorfos antecenomanianos do "Grés do Buçaco" (Lousã, Portugal). Ciências da Terra 10, 51-64.

Tucholke, B.E., Sawyer, D.S., Sibuet, J.-C., 2007. Breakup of the Newfoundland-Iberia rift. In: Karner, G.D., Manatschal, G., Pinheiro, L.M. (Eds.), Imaging, Mapping and Modelling Continental Lithosphere Extension and Breakup. Geological Society Special Publications, London, pp.9-46.

Valle Aguado, B., Azevedo, M.R., Schaltegger, U., Catalán, J.R., Nolan, J., 2005. U-Pb zircon and monazite geochronology of Variscan magmatism related to syn-convergence extension in Central Northern Portugal. Lithos 82, 169-184.

Valle Aguado, B., Azevedo, M.R., Nolan, J. Medina J., Costa, M.M., Corfu, F., Martinez Catalán, J.R., 2017. Granite emplacement at the termination of a major Variscan transcurrent shear zone: The late collisional Viseu batholith. Journal of Structural Geology 98, 15-37.

Vázquez-Vílchez M., Jabaloy-Sánchez A., Azor A., Stuart F., Persano C., Alonso-Chaves F.M., Martín-Parra L.M., Matas J., García-Navarro E., 2015. Mesozoic and Cenozoic exhumation history of the SW Iberian Variscides inferred from low-temperature thermochronology. Tectonophysics 663, 110-121.

Weissel, J.K., Karner, G.D., 1989. Flexural uplift of rift flanks due to mechanical unloading of the lithosphere during extension, J. Geophys. Res. 94, 13919-13950.

Whitmarsh R.B., Miles, P.R., 1995. Models of the development of the West Iberia rifted continental margin at $40^{\circ} 30^{\prime} \mathrm{N}$ deduced from surface and deep-tow magnetic anomalies. Journal of Geophysical Research 100, B3, 3789-3806.

Whitmarsh, R.B., Manatschal, G., Minshull, T.A., 2001. Evolution of magma-poor continental margins from rifting to seafloor spreading. Nature 413, 150-154.

Wilson, R.C.L., Hiscott, R.N., Willis, M.G., \& Gradstein, F.M., 1989. The Lusitanian basin of west-central Portugal: Mesozoic and Tertiary tectonic, stratigraphy, and subsidence history. American Association of Petroleum Geologists Memoir, 46, 341-361. 
732 Wilson R.C.L., Manatschal, G., Wise, S., 2001. Rifting along non volcanic passive margins: 733 stratigraphic and seismic evidence from the Mesozoic successions of the Alps and western 3734 Iberia. In: Wilson RCL, Whitmarsh RB, Taylor B, Froitzheim N (eds) Non-volcanic rifting 735 of continental margins: a comparison of evidence from land and sea. Geol Soc Spec Publ $736 \quad 187: 429-452$. 


\section{Tables}

Table 1. Sample details (locality, lithology, U-Pb age, coordinates in WGS84 projection system, and altitude) and apatite fission-track results.

n - number of apatite crystals counted; s, i and d subscripts denote spontaneous, induced and dosimeter; $\rho$ - track density ( $10^{5}$ tracks $\left./ \mathrm{cm} 2\right) ; \mathrm{N}$ - number of tracks counted; $\mathrm{P}(\chi 2)$ - probability of obtaining Chi-square value $\left(\chi^{2}\right)$ for $\mathrm{n}$ degrees of freedom (where $\mathrm{n}=$ number of crystals -1 ); Age $\pm 1 \sigma$ - central age \pm 1 standard error (Galbraith and Laslett, 1993); MTL - mean track length $(\mu \mathrm{m})$; SD - standard deviation of track length distribution $(\mu \mathrm{m})$; $\mathrm{N}(\mathrm{L})$ - number of horizontal confined tracks measured ; Dpar - average etch pit diameter parallel to c. Ages were calculated using the zeta calibration method (Hurford and Green, 1983), glass dosimeters CN5 , and a zeta value of $359 \pm 8(\mathrm{JB}) . \mathrm{U} / \mathrm{Pb}$ ages inferred to represent crystallization ages are from (1) Neiva et al. (2009); (2) Valle Aguado et al. (2005); (3) Neiva et al. (2012); (4) Dias et al. (1998); (5) Valle Aguado et al. (2017); (6) Antunes et al. (2008); (7) Pin et al. (2008); (8) Solá et al. (2009); (9) Lima et al. (2012).

\section{Figures}

Figure 1. Simplified geological map with squares marking sample location, and showing sample reference, AFT ages (top, in Ma) and track length (bottom, in $\mu \mathrm{m}$ ). Color of the squares (blue, green, orange and yellow) corresponds respectively to the western unit, central unit, eastern unit and samples from the south of the PTBF. CF and VF - Chaves and Vilariça faults, respectively; PTBF - Porto-Tomar-Badajoz Fault. MPF - Messejana-Placencia Fault with mafic dyke intruded in most of its extension. Cyan lines - reverse faults bounding the Serra da Estrela popup. Inset top left - lithostratigraphy, NLB, CLB and SLB - northern, central and southern LB, respectively. AB - Alentejo Basin. GB - Galicia Bank. IAP and TAP - Iberian and Tagus Abyssal Plains, respectively. Inset bottom left - Western Iberia-Newfoundland conjugate margins (WICM and NFCM, respectively). Black, red and white dashed lines mark the boundaries between proximal, thinned, exhumed and oceanic domains (after Nirrengarten et al., 2017). Image downloaded from EMODnet (https://portal.emodnet-bathymetry.eu/). 
Figure 2. Synthetic lithostratigraphic logs of the onshore and offshore Lusitanian Basin between Figueira da Foz (north) and Nazaré (south) (see Fig. 3 for location). Onshore data are from Rocha et al. (1981), Wilson et al. (1989) and Azerêdo (2007). Offshore datafrom figure 14 in Alves et al. (2009). R1 to R4 in black are from Alves et al. (2009).

Figure 6. FT modelling of samples from the western unit. No additional constraint has been set as no Mesozoic sedimentary cover is preserved. A: sample BAR, B: sample GRJ, C: sample ALH and D: sample SVG.

Figure 3. Depth to basement map obtained in the Lusitanian Basin by modelling of seismic velocities and magnetic and gravity anomalies (SEEBASE, FrogTech, 2012). Note that in this model the deepest depocenter in the onshore LB is around $-8,000 \mathrm{~m}$.

Figure 4. FT results: track length vs FT age by geographic region. Colours correspond to the location of the samples: blue for western unit, green for central unit, and orange for eastern unit. Sample J (in black) is located in the south of the studied area (Ossa Morena Zone).

Figure 5. FT modelling of samples from the central unit. Two boxes at the beginning and at the end of the history have been set; additional boxes depend on the samples. A - sample SCD with constraints only at the beginning and the end ; B - sample NEL with a box during Early Cretaceous justified by the presence of Lower Cretaceous sedimentary rocks on top of the basement east of the PTBF; C - sample NEL with an additional box during Triassic times, consistent with the presence of basement of this domain at the surface during that period, as attested by the thermal history of sample SCD; D - sample VTA with modelling conditions similar to sample NEL; E - sample AN; F - sample COI3, for which residence at the surface during Triassic times is necessary as the stratigraphic age of the sample is Triassic. Colors of single thermal history correspond to the relative probability of the posterior model, red color being the higher probability (Gallagher, 2012). Color scale is presented on the right of the models. 
800 Figure 7. FT modelling for samples from the eastern unit. A - sample CST; B - sample MTG1; $\mathrm{C}$ - sample SRT; and D - sample $\mathrm{T}$, for which the model assumes the presence of the sample close to the surface during Triassic times, and shows lower temperature than for the other samples during the Jurassic.

804

Figure 8. Interpreted evolution of the LB's eastern margin since the Triassic, supported by the geological and AFT data reported here. A - late-Variscan orogenic collapse to Triassic early rifting of Pangaea. B - main subsidence during the Jurassic, including the Hettangian (evaporites up to 3,000 m thick) and overlying rocks up to the Lower Kimmeridgian (Carbonated rocks ca. 3,000 m thick). C - Basin uplift in the Upper Kimmeridgian and Tithonian. D - major rift shoulder uplift, with injection of alkaline dykes (thick red line) into Jurassic sediments following lithospheric scale discontinuities (Grange et al., 2008).

Figure 9: Geodynamic model suggested from data for the evolution of the western Iberia margin. MAR: middle Atlantic ridge.

Supplementary materials

Figure S1: Sketch with the yield strength envelope (YSE) for continental lithosphere. Note that, prior to whole lithosphere failure, two elastic cores exist that can vanish due to increase in time, and/or heat and/or stress. For rifting, the YSE must be flipped around the ordinate axis.

Figure S2a-b-c: representation of fission-track ages in radial plot distributions.

Figure S3: histograms of horizontal confined track-length distribution for all samples. 


\begin{tabular}{|c|c|c|c|c|c|c|c|c|c|c|c|c|c|c|c|c|c|c|c|c|}
\hline Code & Lithotype & $\begin{array}{l}\text { U-Pb } \\
\text { age } \\
\text { (Ma) }\end{array}$ & $\begin{array}{l}\text { Latitude } \\
\qquad\left(^{\circ}\right)\end{array}$ & $\begin{array}{l}\text { Longitude } \\
\left(^{\circ}\right)\end{array}$ & $\begin{array}{c}\text { Altitude } \\
\text { (m) }\end{array}$ & $\mathbf{n}$ & $r_{s}$ & $\mathbf{N}_{\mathbf{s}}$ & $r_{i}$ & $\mathrm{Ni}$ & $r_{d}$ & $\mathbf{N}_{\mathrm{d}}$ & $P\left(c^{2}\right)$ & RE & $\begin{array}{c}U \\
(\mathrm{ppm})\end{array}$ & $\begin{array}{l}\mathrm{FT} \\
\text { age } \\
\text { (Ma) }\end{array}$ & $\mathbf{N}$ & $\begin{array}{c}\mathrm{L} \\
(\mu \mathrm{m})\end{array}$ & $\begin{array}{c}\text { SD } \\
(\mu \mathrm{m})\end{array}$ & $\begin{array}{l}\text { Dpar } \\
(\mu \mathrm{m})\end{array}$ \\
\hline
\end{tabular}

\section{Western Unit}

\begin{tabular}{|c|c|c|c|c|c|c|c|c|c|c|c|c|c|c|c|c|c|c|c|c|}
\hline BAR & $\begin{array}{c}\text { biotite } \\
\text { granodiorite }\end{array}$ & $\begin{array}{c}319 \pm 4 \\
(4)\end{array}$ & 41.12307 & -7.88465 & 278 & 23 & 0.565 & 971 & 0.946 & 1626 & 7.024 & 6686 & 91.1 & 0.1 & 16 & $75 \pm 4$ & 87 & $12.0 \pm 0.1$ & 1.3 & $1.4 \pm 0.1$ \\
\hline GRJ & monzonite & & 41.10244 & -8.00113 & 118 & 22 & 1.27 & 960 & 1.753 & 1325 & 6.717 & 6686 & 79.1 & 0.7 & 32 & $87 \pm 4$ & 58 & $12.6 \pm 0.2$ & 1.8 & $1.4 \pm 0.1$ \\
\hline CIF & $\begin{array}{l}\text { two mica } \\
\text { granite }\end{array}$ & & 41.07861 & -8.1011 & 357 & 21 & 2.332 & 1770 & 2.427 & 1842 & 6.901 & 6686 & 60.7 & 0.8 & 43 & $118 \pm 5$ & 8 & $12.6 \pm 0.5$ & 1.5 & $1.5 \pm 0.1$ \\
\hline ALH & $\begin{array}{l}\text { porphyroid } \\
\text { monzonite }\end{array}$ & & 40.97636 & -8.0209 & 1105 & 20 & 2.452 & 1910 & 2.452 & 1936 & 7.086 & 6686 & 87.6 & 0,0 & 43 & $124 \pm 5$ & 100 & $12.6 \pm 0.1$ & 1.4 & $1.4 \pm 0.1$ \\
\hline SVG & $\begin{array}{c}\text { two mica } \\
\text { granite }\end{array}$ & $\begin{array}{c}308 \pm 1 \\
(2)\end{array}$ & 40.67345 & -8.33757 & 440 & 22 & 1.863 & 1099 & 1.78 & 1050 & 6.348 & 6686 & 97.7 & 0,0 & 34 & $118 \pm 6$ & 22 & $12.9 \pm 0.2$ & 1,0 & $1.3 \pm 0.1$ \\
\hline
\end{tabular}

\section{Central Unit}

\begin{tabular}{|c|c|c|c|c|c|c|c|c|c|c|c|c|c|c|c|c|c|c|c|c|}
\hline AN & $\begin{array}{c}\text { biotite } \\
\text { granodiorite }\end{array}$ & $\begin{array}{c}319 \pm 4 \\
(4)\end{array}$ & 41.08813 & -7.7996 & 530 & 20 & 1.459 & 1005 & 1.158 & 798 & 6.174 & 6213 & 11.7 & 12.1 & 23 & $137 \pm 8$ & 100 & $12.5 \pm 0.1$ & 1.2 & $1.7 \pm 0.1$ \\
\hline VTA & $\begin{array}{l}\text { two mica } \\
\text { granite }\end{array}$ & $\begin{array}{c}308 \pm 1 \\
(2)\end{array}$ & 40.69365 & -8.08034 & 612 & 20 & 0.888 & 1089 & 0.635 & 779 & 6.286 & 6213 & 89.7 & 0.2 & 12 & $156 \pm 8$ & 100 & $12.2 \pm 0.1$ & 1.4 & $1.4 \pm 0.2$ \\
\hline NEL & $\begin{array}{l}\text { porphyroid } \\
\text { monzonite }\end{array}$ & $\begin{array}{c}297 \pm 3 \\
(3)\end{array}$ & 40.53177 & -7.86412 & 405 & 20 & 3.239 & 2212 & 2.184 & 1492 & 6.532 & 6686 & 86.1 & 0,0 & 41 & $172 \pm 7$ & 100 & $12.7 \pm 0.2$ & 1.6 & $1.5 \pm 0.1$ \\
\hline SCD & monzonite & $\begin{array}{c}198 \pm 1 \\
(5)\end{array}$ & 40.39512 & -8.099 & 206 & 18 & 5.592 & 2220 & 3.358 & 1333 & 6.471 & 6686 & 49,0 & 2.3 & 63 & $191 \pm 8$ & 100 & $13.4 \pm 0.1$ & 1,0 & $1.5 \pm 0.1$ \\
\hline
\end{tabular}

\section{Eastern Unit}

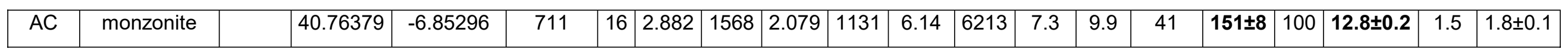




\begin{tabular}{|c|c|c|c|c|c|c|c|c|c|c|c|c|c|c|c|c|c|c|c|c|}
\hline CEL & $\begin{array}{l}\text { porphyroid } \\
\text { monzonite }\end{array}$ & $\begin{array}{c}305 \pm 4 \\
(2)\end{array}$ & 40.62911 & -7.41561 & 448 & 19 & 0.376 & 534 & 0.418 & 594 & 6.963 & 6686 & 20.3 & 15.4 & 7 & $110 \pm 9$ & 16 & $13.3 \pm 0.3$ & 1,0 & $1.4 \pm 0.1$ \\
\hline MTG1 & monzonite & $\begin{array}{c}301 \pm 3 \\
(1)\end{array}$ & 40.41253 & -7.55279 & 1224 & 23 & 0.684 & 1031 & 0.808 & 1218 & 6.655 & 6686 & 69.1 & 1.1 & 15 & $100 \pm 5$ & 85 & $12.6 \pm 0.2$ & 1.4 & $1.4 \pm 0.1$ \\
\hline SRT & $\begin{array}{l}\text { porphyroid } \\
\text { monzonite }\end{array}$ & & 40.31532 & -7.28675 & 507 & 21 & 2.743 & 1684 & 3.349 & 2056 & 6.409 & 6686 & 96,0 & 0,0 & 64 & $94 \pm 4$ & 101 & $12.3 \pm 0.1$ & 1.3 & $1.4 \pm 0.1$ \\
\hline CST & $\begin{array}{l}\text { two mica } \\
\text { granite }\end{array}$ & $\begin{array}{c}310 \pm 1 \\
(6)\end{array}$ & 40.07818 & -7.49373 & 590 & 17 & 1.997 & 1206 & 3.104 & 1875 & 6.778 & 6686 & 31.7 & 6,0 & 56 & $78 \pm 4$ & 92 & $12.6 \pm 0.2$ & 1.7 & $1.7 \pm 0.1$ \\
\hline $\mathrm{T}$ & $\begin{array}{l}\text { porphyroid } \\
\text { monzonite }\end{array}$ & $\begin{array}{c}305 \pm 6 \\
(8)\end{array}$ & 39.41024 & -7.62334 & 331 & 19 & 6.447 & 2824 & 4.406 & 1930 & 6.23 & 6213 & 1.7 & 10.9 & 86 & $162 \pm 8$ & 101 & $12.2 \pm 0.2$ & 1.6 & $1.8 \pm 0.1$ \\
\hline
\end{tabular}

\section{Lusitanian Basin}

\begin{tabular}{|c|c|c|c|c|c|c|c|c|c|c|c|c|c|c|c|c|c|c|c|}
\hline COI3 & $\begin{array}{c}\text { granite in } \\
\text { Triassic } \\
\text { conglomerate }\end{array}$ & 40.244 & -8.39941 & 149 & 20 & 2.256 & 1135 & 1.748 & 879 & 6.84 & 6686 & 79.1 & 0.1 & 31 & $157 \pm 8$ & 100 & $12.0 \pm 0.1$ & 1.3 & $1.4 \pm 0.1$ \\
\hline
\end{tabular}

\section{Ossa-Morena Zone}

\begin{tabular}{|c|c|c|c|c|c|c|c|c|c|c|c|c|c|c|c|c|c|c|c|c|}
\hline$J$ & $\begin{array}{l}\text { Porphyrid 2- } \\
\text { micas granite }\end{array}$ & $\begin{array}{c}324 \pm 1 \\
(9)\end{array}$ & 38.84073 & -7.89542 & 210 & 18 & 0.543 & 415 & 0.619 & 473 & 6.185 & 6213 & 60.8 & 3.1 & 13 & $97 \pm 7$ & 10 & $13.2 \pm 0.4$ & 1.2 & $1.6 \pm 0.1$ \\
\hline TOR & gabbro & $\begin{array}{c}352 \pm 2 \\
(7)\end{array}$ & 38.29957 & -8.22976 & 61 & 15 & 0.248 & 75 & 0.315 & 238 & 6.286 & 6686 & 90.5 & 0 & 6 & $88 \pm 16$ & - & - & - & $1.4 \pm 0.1$ \\
\hline
\end{tabular}




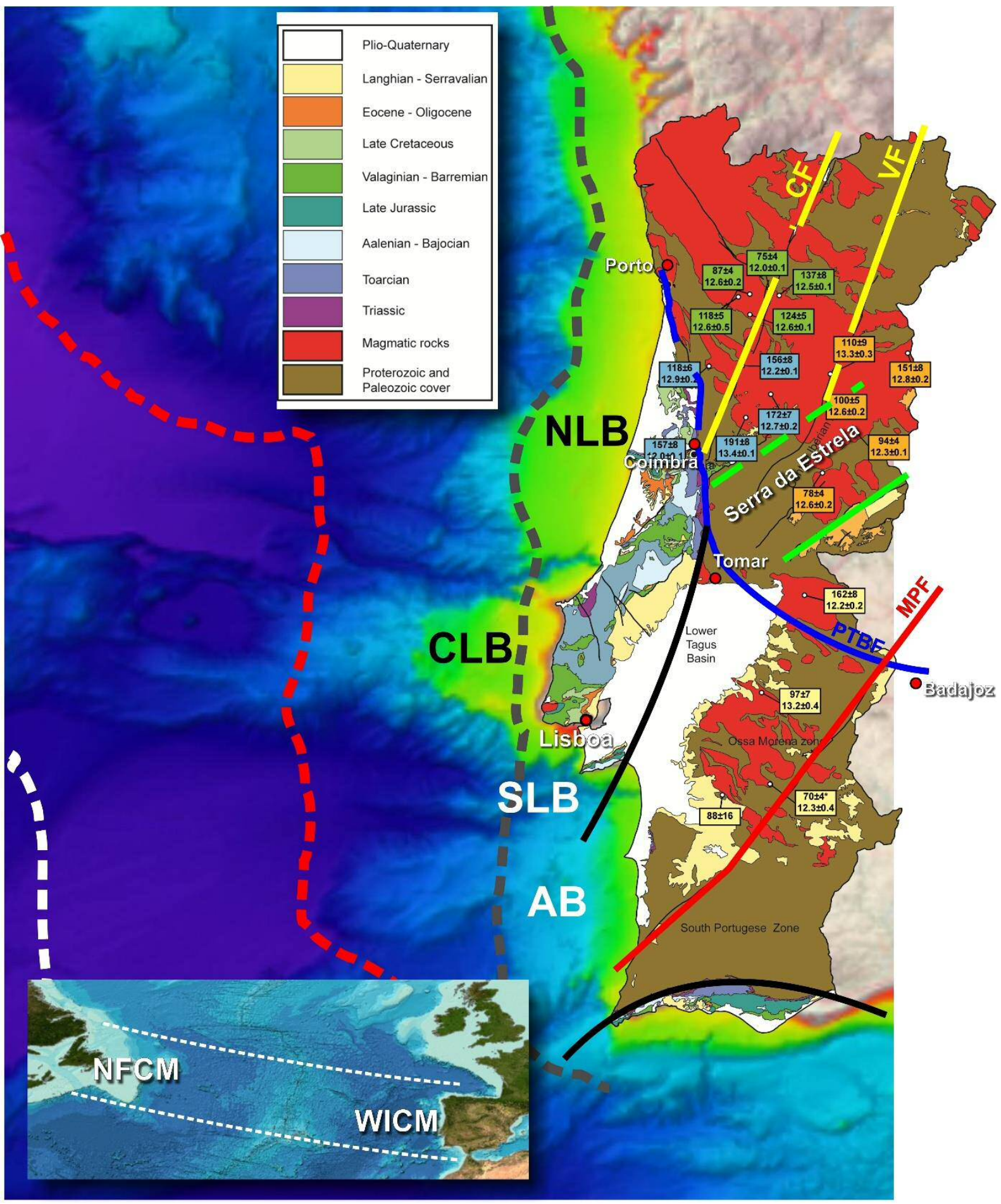

Figure 1. Simplified geological map with squares marking sample location, and showing sample reference, AFT ages (top, in Ma) and track length (bottom, in $\mu \mathrm{m}$ ). Color of the squares (blue, green, orange and yellow) corresponds respectively to the western unit, central unit, eastern unit and samples from the south of the PTBF. CF and VF - Chaves and Vilariça faults, respectively; PTBF - Porto-Tomar-Badajoz Fault. MPF - Messejana-Placencia Fault with mafic dyke intruded in most of its extension. Cyan lines - reverse faults bounding the Serra da 
Estrela pop-up. Inset top left - lithostratigraphy, NLB, CLB and SLB - northern, central and southern LB, respectively. AB - Alentejo Basin. GB - Galicia Bank. IAP and TAP - Iberian and Tagus Abyssal Plains, respectively. Inset bottom left - Western Iberia-Newfoundland conjugate margins (WICM and NFCM, respectively). Black, red and white dashed lines mark the boundaries between proximal, thinned, exhumed and oceanic domains (after Nirrengarten et al., 2017). Image downloaded from EMODnet (https://portal.emodnet-bathymetry.eu/). 


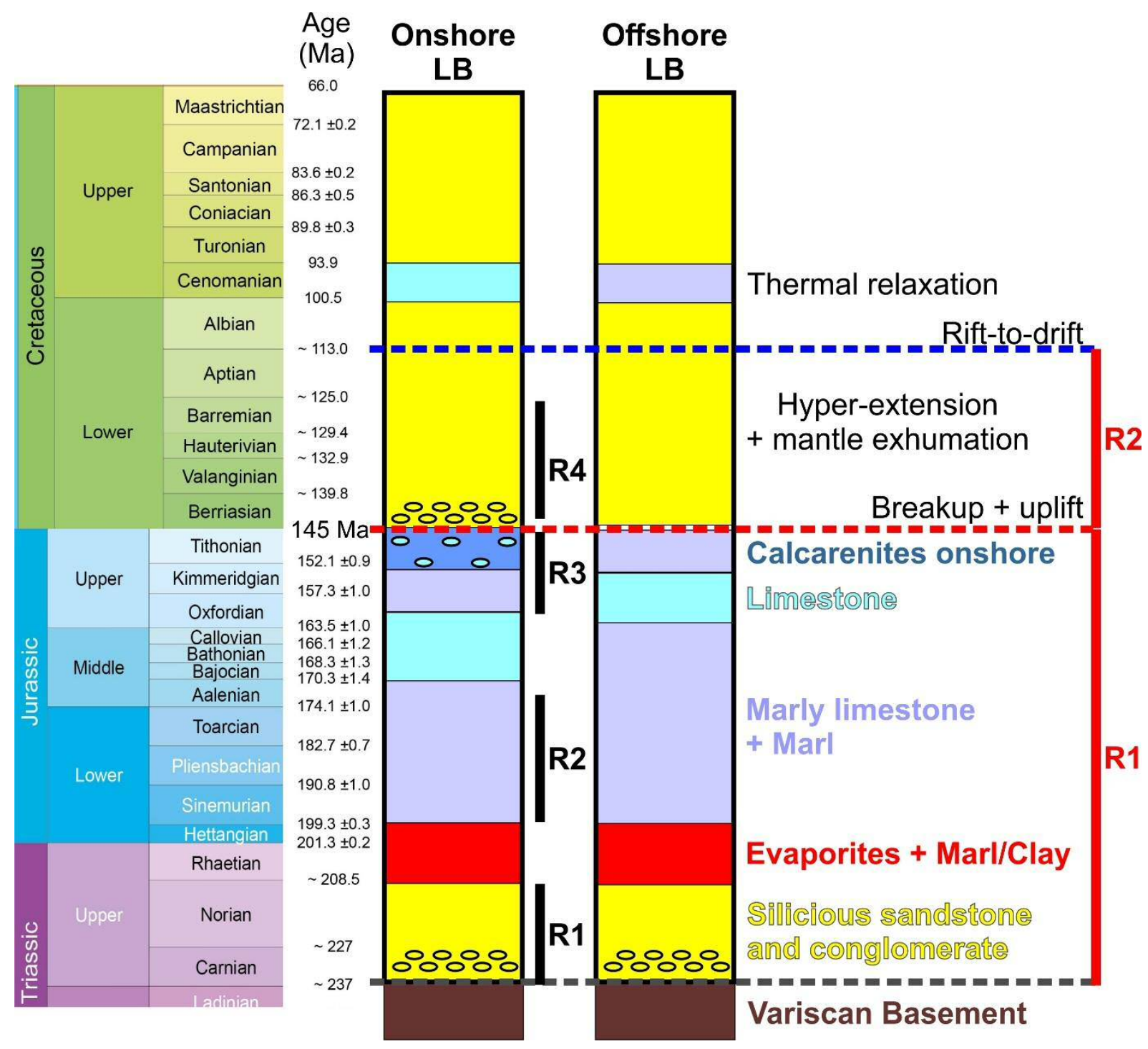

Figure 2. Synthetic lithostratigraphic logs of the onshore and offshore Lusitanian Basin between Figueira da Foz (north) and Nazaré (south) (see Fig. 3 for location). Onshore data are from Rocha et al. (1981), Wilson et al. (1989) and Azerêdo (2007). Offshore datafrom figure 14 in Alves et al. (2009). R1 to R4 in black are from Alves et al. (2009). 


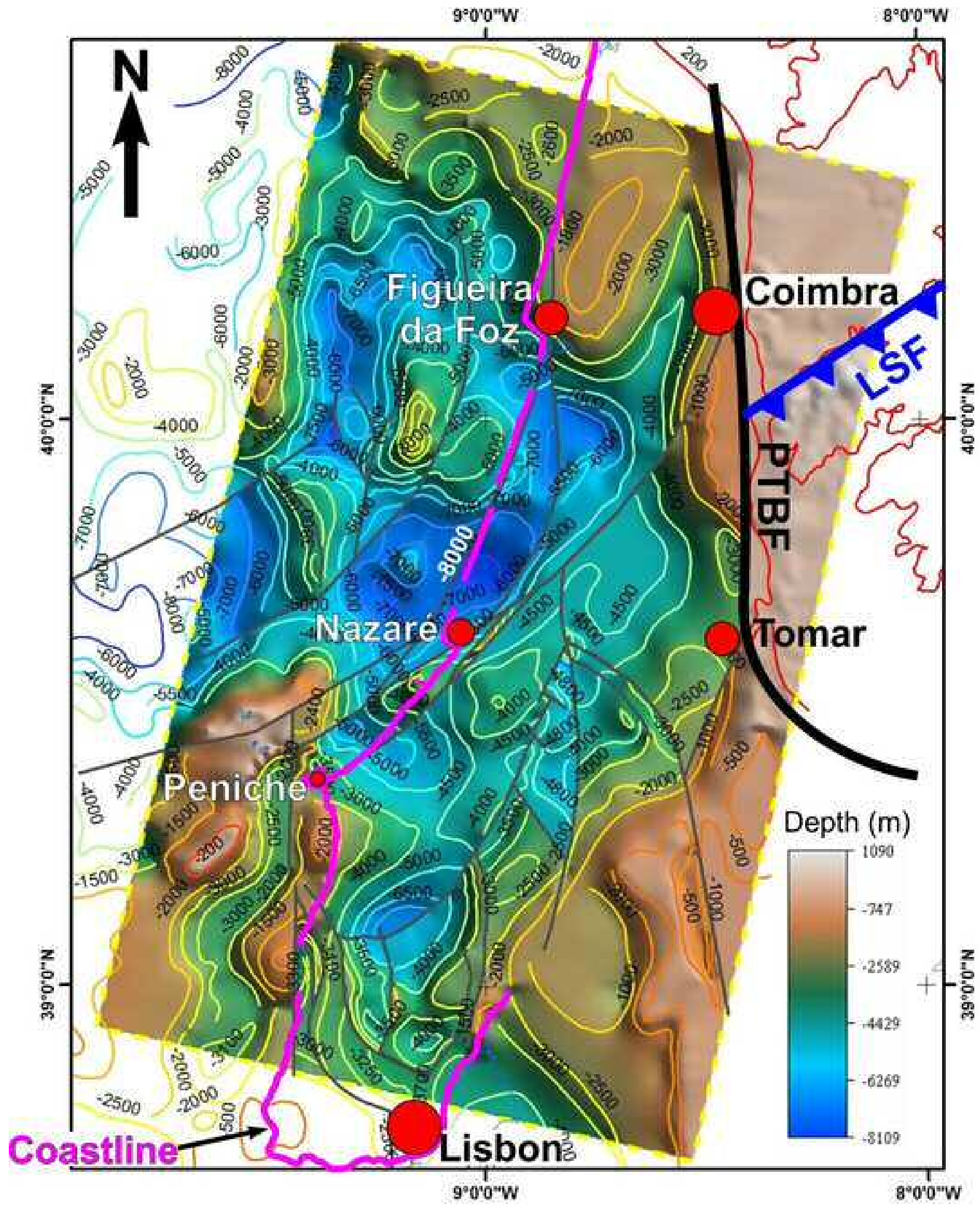




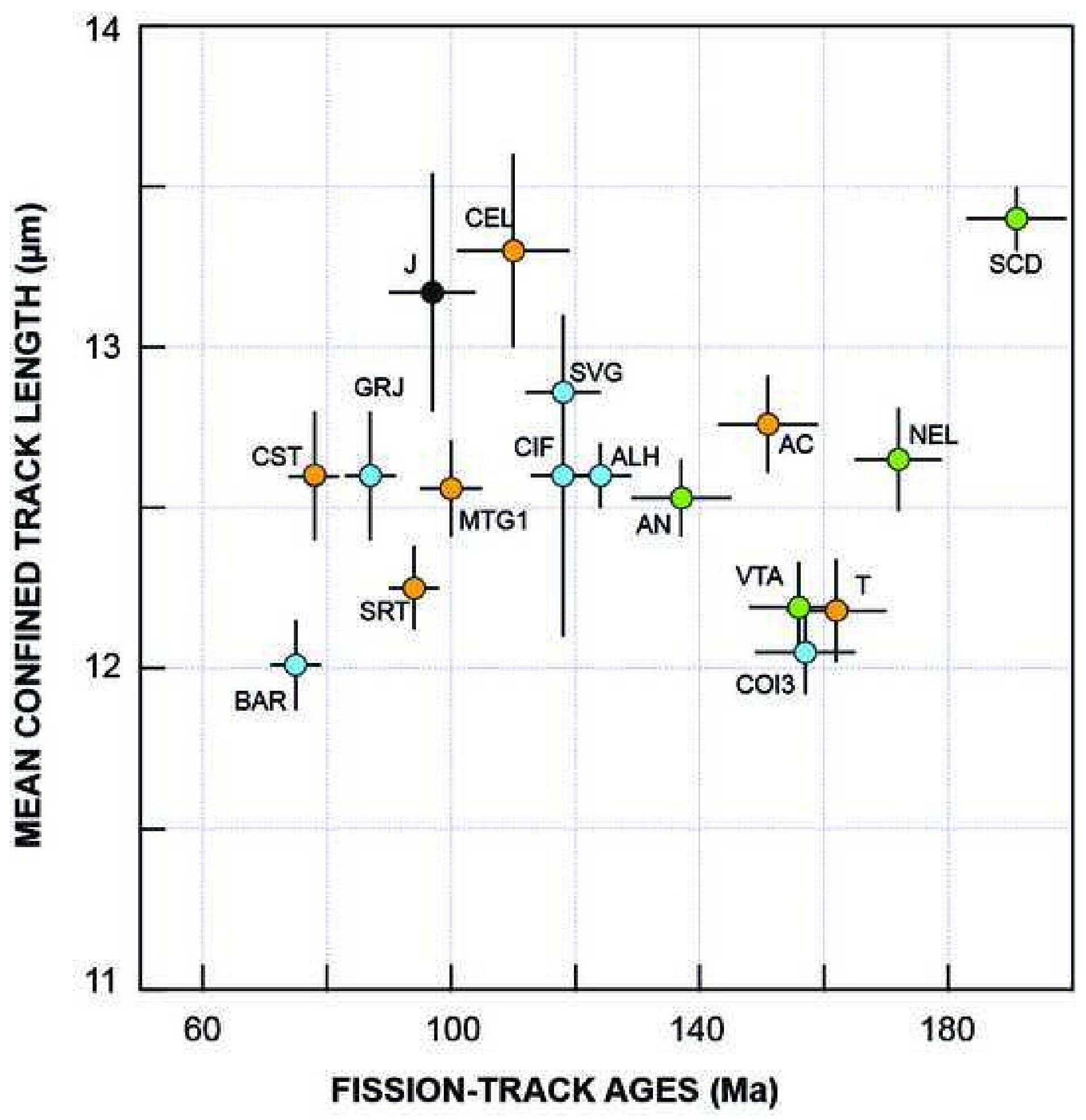



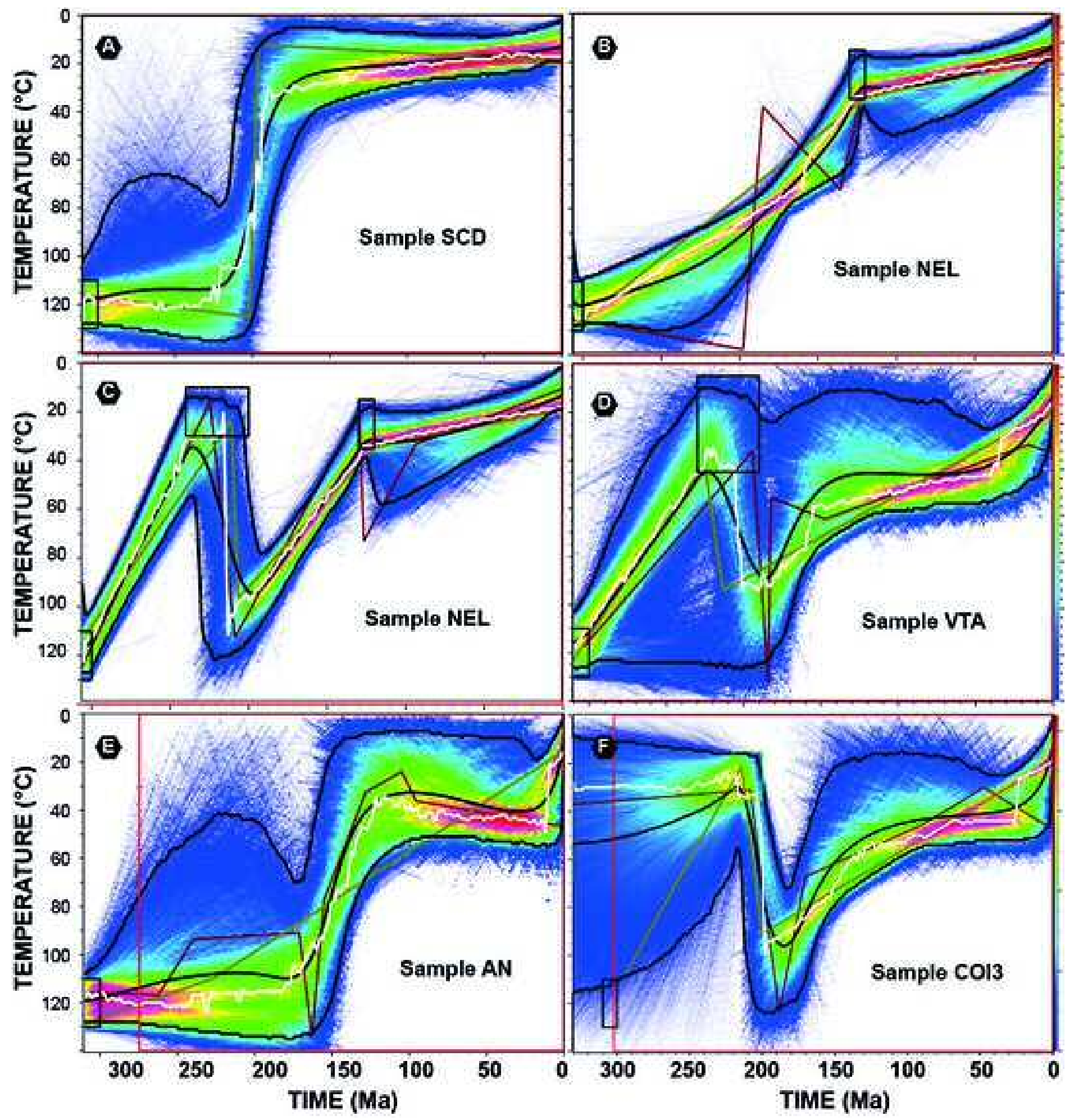

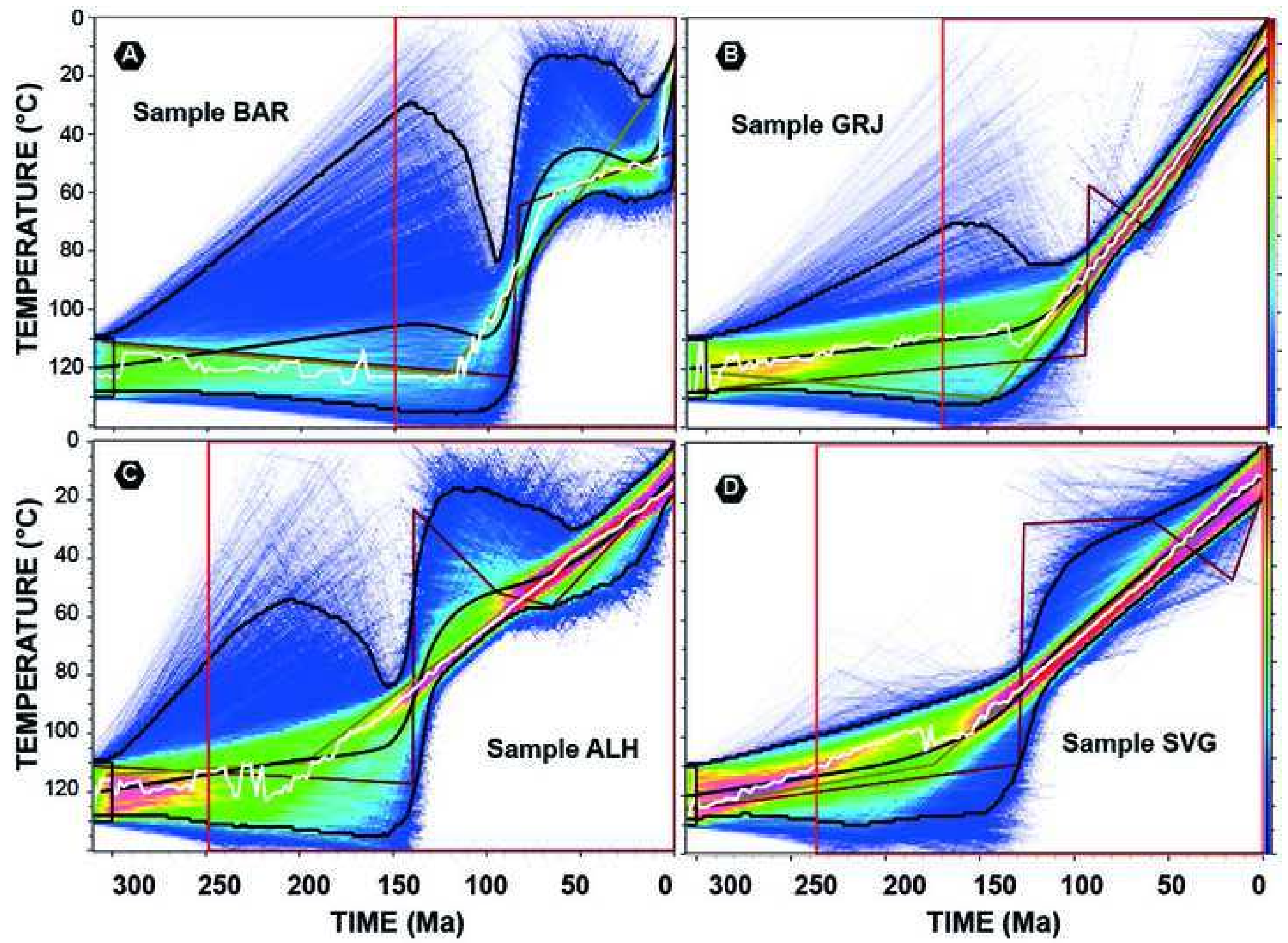

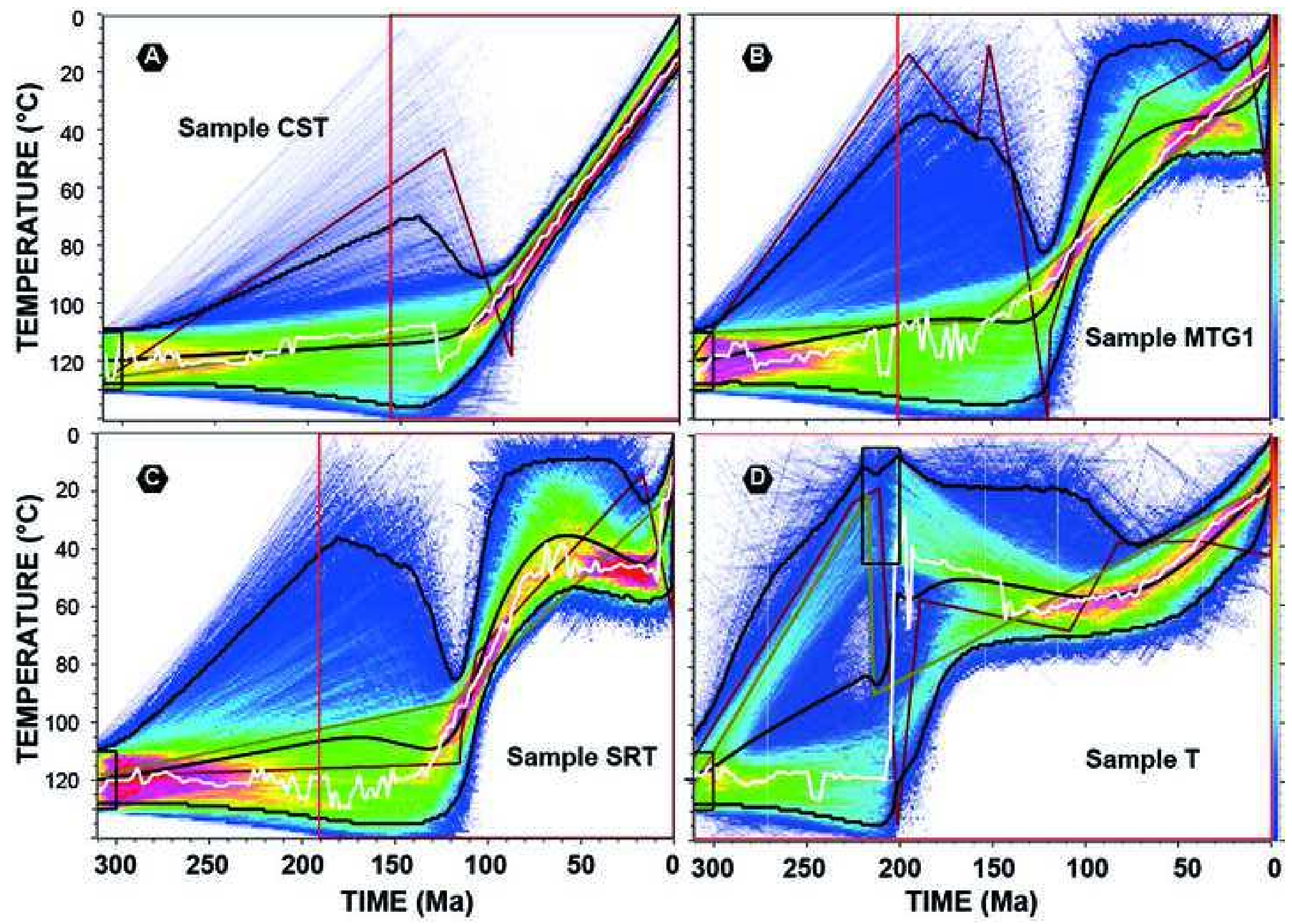


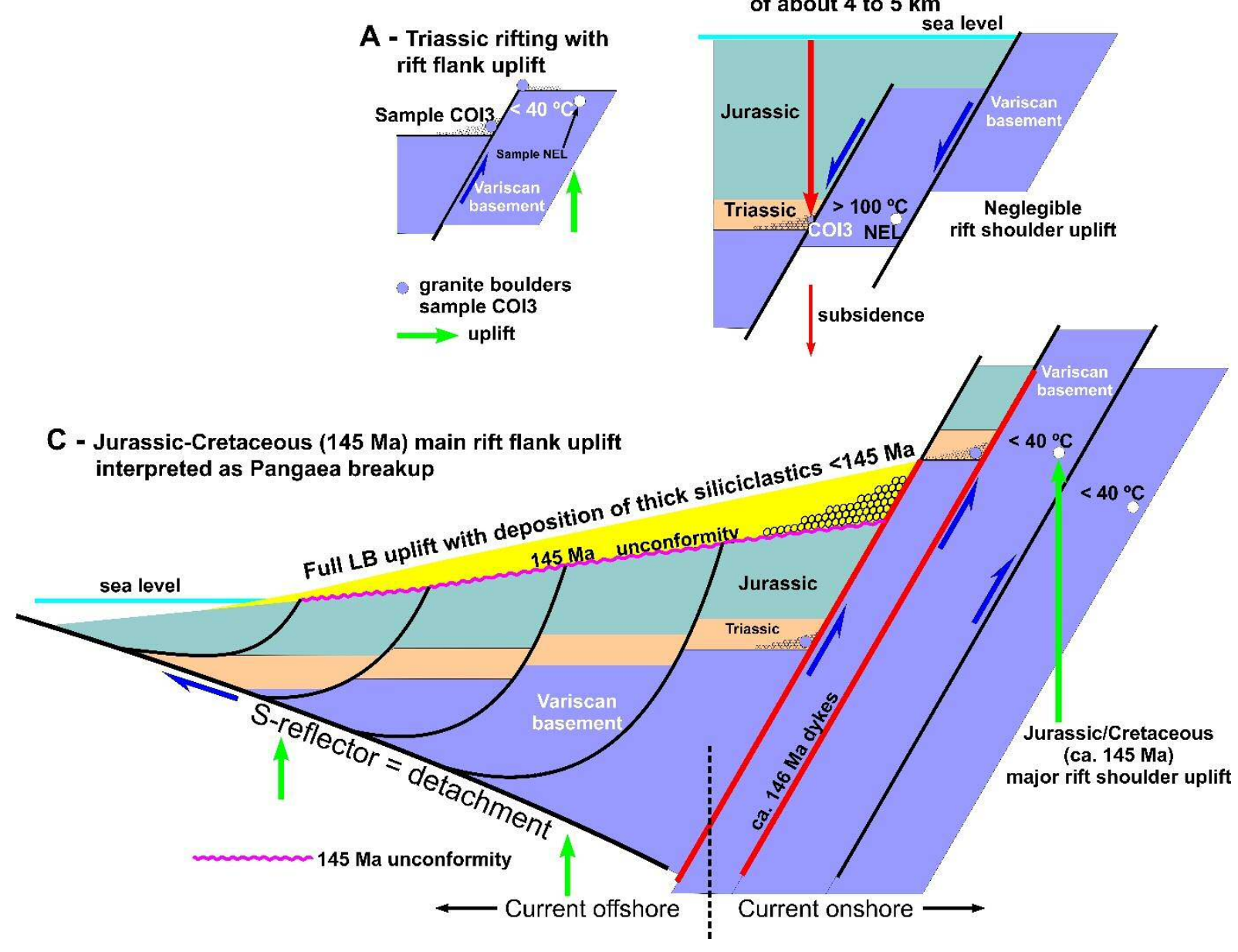

B - Jurassic main subsidence of about 4 to $5 \mathrm{~km}$
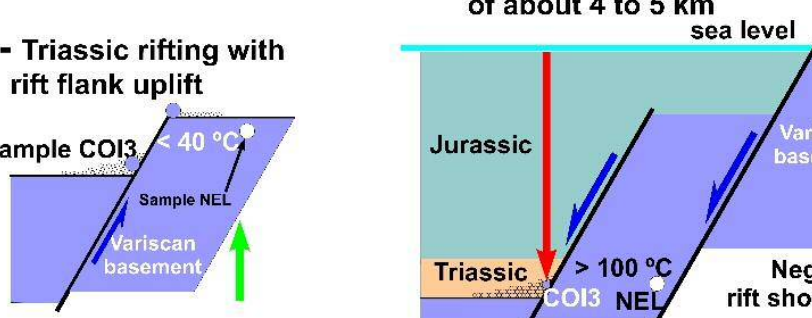

granite boulders sample $\mathrm{CO} 3$

$\Rightarrow$ uplift

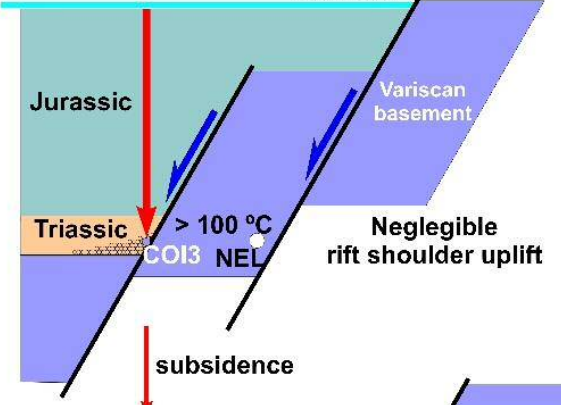

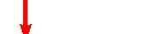

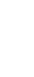

Figure 8. Interpreted evolution of the LB's eastern margin since the Triassic, supported by the geological and AFT data reported here. A - late-Variscan orogenic collapse to Triassic early rifting of Pangaea. B - main subsidence during the Jurassic, including the Hettangian (evaporites up to $3,000 \mathrm{~m}$ thick) and overlying rocks up to the Lower Kimmeridgian (Carbonated rocks ca. 3,000 m thick). C - Basin uplift in the Upper Kimmeridgian and Tithonian. D - major rift shoulder uplift, with injection of alkaline dykes (thick red line) into Jurassic sediments following lithospheric scale discontinuities (Grange et al., 2008). 
A - Rift 1, ca. 215-150 Ma

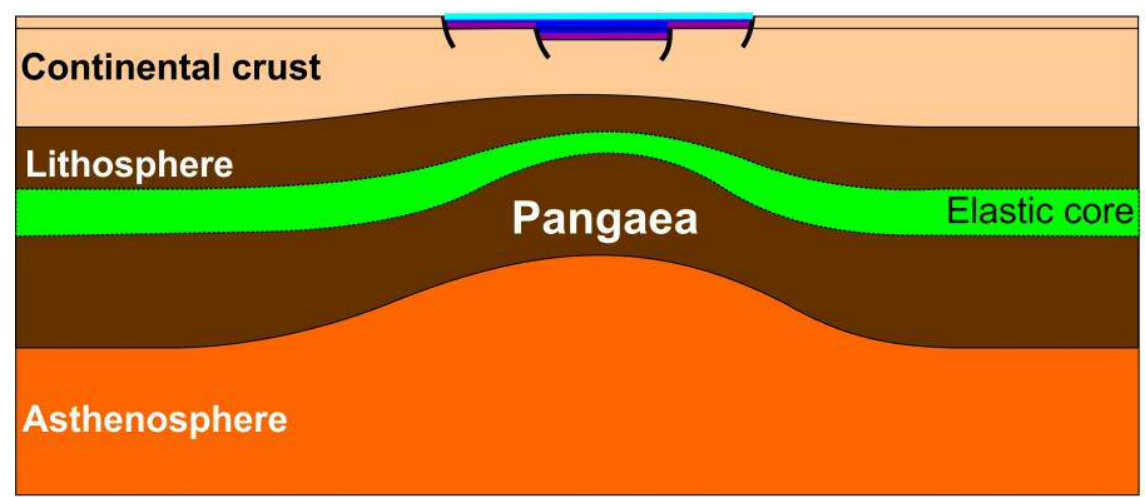

B - WLF, ca. 150-145 Ma

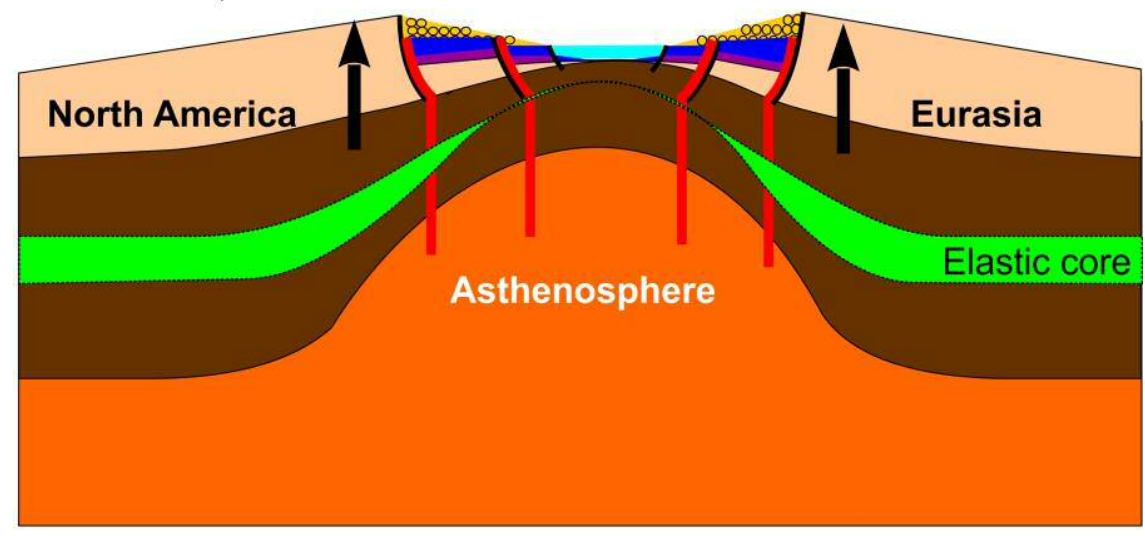

C - Rift 2 to rift-to-drift, ca. $145-110 \mathrm{Ma}$

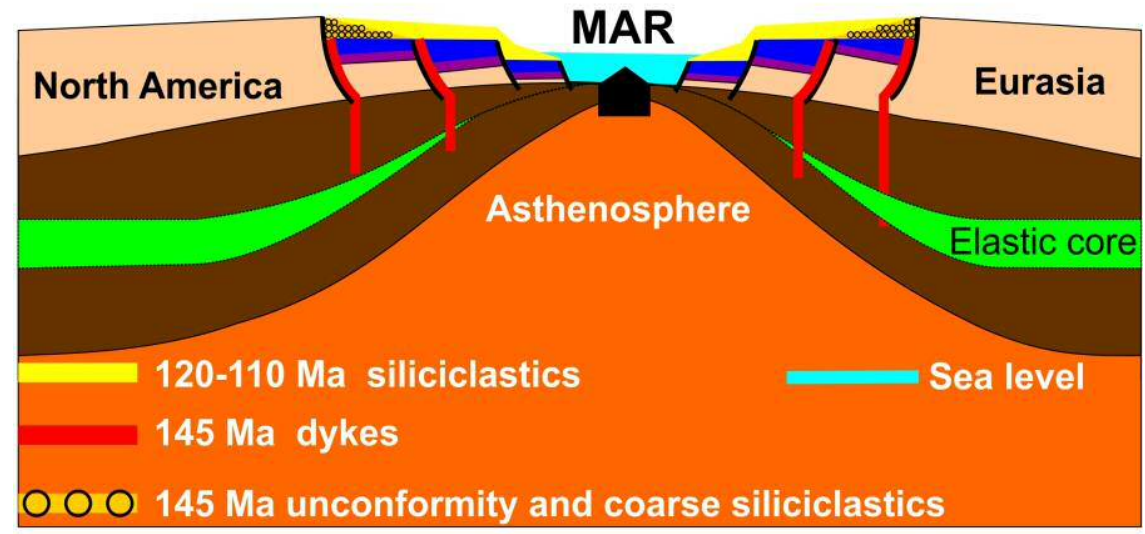

\section{0-150 Ma marine carbonates}

\section{Ma evaporite}

Figure 9: Geodynamic model suggested from data for the evolution of the western Iberia margin. MAR: middle Atlantic ridge. 
Click here to access/download Supplementary material for online publication only Tecto 14429_Figure S1.docx

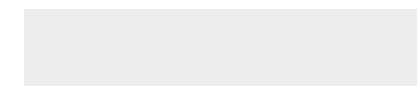


Click here to access/download Supplementary material for online publication only Tecto 14429_Figure S2abc.docx

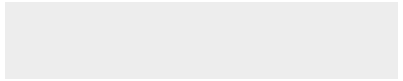


Click here to access/download Supplementary material for online publication only Tecto 14429_Figure S3.docx

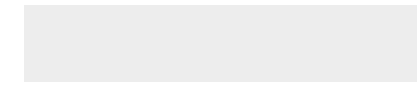


Click here to access/download RDM Data Profile XML TECTO14429_DataProfile.xml

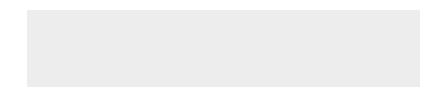




\section{Declaration of interests}

The authors declare that they have no known competing financial interests or personal relationships that could have appeared to influence the work reported in this paper.

$\square$ The authors declare the following financial interests/personal relationships which may be considered as potential competing interests:

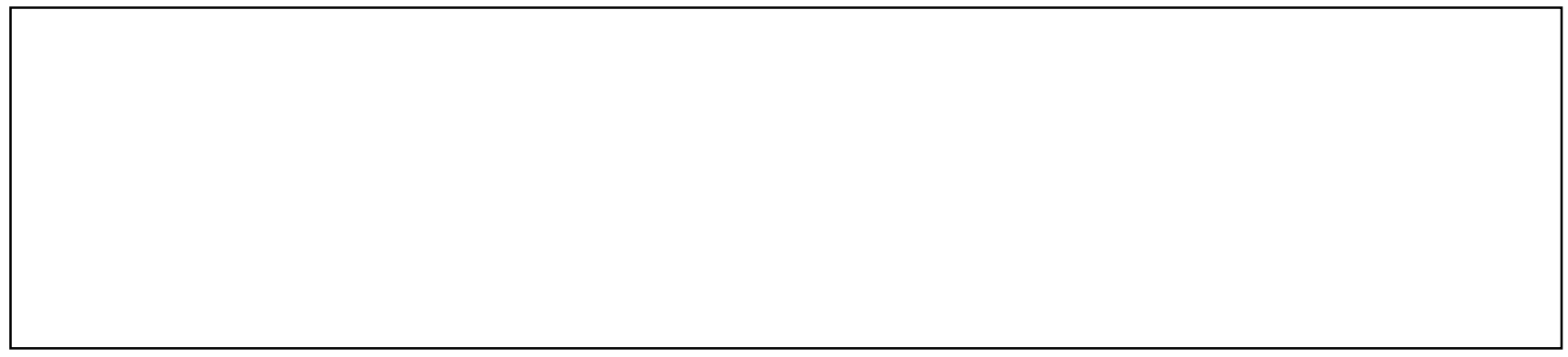


J. Barbarand : methodology - investigation - data curation - Writing - Review \& Editing F.O. Marques : conceptualization - Writing - Review \& Editing - funding acquisition A. Hildenbrand : resources - Writing - Review \& Editing R. Pinna Jamme : investigation - data curation C.R. Nogueira : resources 